Article

\title{
Counter-Current Leaching of Low-Grade Laterites with Hydrochloric Acid and Proposed Purification Options of Pregnant Solution
}

\author{
Christiana Mystrioti ${ }^{1}$, Nymphodora Papassiopi ${ }^{2}$, Anthimos Xenidis ${ }^{2}$ and \\ Konstantinos Komnitsas $1, *$ (D) \\ 1 Department Mineral Resources Engineering, Technical University Crete, 73100 Chania, Greece; \\ chmistrioti@metal.ntua.gr \\ 2 School of Mining and Metallurgical Engineering, National Technical University of Athens, 15780 Zografos, \\ Greece; papasiop@metal.ntua.gr (N.P.); axen@metal.ntua.gr (A.X.) \\ * Correspondence: komni@mred.tuc.gr; Tel.: +30-28210-37686
}

Received: 22 November 2018; Accepted: 14 December 2018; Published: 18 December 2018

\begin{abstract}
A hydrochloric acid hydrometallurgical process was evaluated for $\mathrm{Ni}$ and Co extraction from a low-grade saprolitic laterite. The main characteristics of the process were (i) the application of a counter-current mode of operation as the main leaching step (CCL), and (ii) the treatment of pregnant leach solution (PLS) with a series of simple precipitation steps. It was found that, during $\mathrm{CCL}$, co-dissolution of Fe was maintained at very low levels, i.e., about $0.6 \%$, which improved the effectiveness of the subsequent PLS purification step. The treatment of PLS involved an initial precipitation step for the removal of trivalent metals, $\mathrm{Fe}, \mathrm{Al}$, and $\mathrm{Cr}$, using $\mathrm{Mg}(\mathrm{OH})_{2}$. The process steps that followed aimed at separating $\mathrm{Ni}$ and $\mathrm{Co}$ from $\mathrm{Mn}$ and the alkaline earths $\mathrm{Mg}$ and $\mathrm{Ca}$, by a combination of repetitive oxidative precipitation and dissolution steps. Magnesium and calcium remained in the aqueous phase, Mn was removed as a solid residue of $\mathrm{Mn}(\mathrm{III})-\mathrm{Mn}$ (IV) oxides, while $\mathrm{Ni}$ and $\mathrm{Co}$ were recovered as a separate aqueous stream. It was found that the overall $\mathrm{Ni}$ and $\mathrm{Co}$ recoveries were $40 \%$ and $38 \%$, respectively. About $45 \%$ of $\mathrm{Ni}$ and $37 \%$ of $\mathrm{Co}$ remained in the leach residue, while $15 \% \mathrm{Ni}$ and $20 \%$ Co were lost in the Mn oxides.
\end{abstract}

Keywords: low-grade saprolitic laterite; counter-current leaching; pregnant leach solution; purification

\section{Introduction}

Nickel is a metal in high demand for industrial applications such as the production of stainless steel, non-ferrous alloys, alloy steels, plating, foundry, and batteries due to its beneficial properties (strength, corrosion resistance, high ductility, good thermal and electric conductivity, magnetic characteristics, and catalytic properties) [1]. Nickel can be found naturally in lateritic ores which are formed by weathering of ultramafic rocks or in sulfide resources. Due to the decline of sulfide deposits and high-grade laterites, there is a need for adapting or optimizing technologies aiming at increasing metal recovery from low-grade laterites in order to make their treatment economically feasible [2]. It is well known that conventional mineral processing techniques, including flotation heavy-media separation and others, cannot be readily applied to oxide ores such as laterites, unlike sulfides, due to the complex nature of the ores and the fact that nickel is hosted in several mineral phases [3].

Hydrometallurgical processes for nickel and cobalt recovery from low-grade laterite ores can be classified as high-pressure acid leaching (HPAL), atmospheric acid leaching (AL), heap leaching (HL), and biological leaching (BL). 
HPAL is often selected for the treatment of low-grade laterite ores, but presents drawbacks such as expensive equipment in order to stand the harsh leaching conditions (typical operating temperature from 250 to $270{ }^{\circ} \mathrm{C}$ ) and high initial capital cost [4,5].

$\mathrm{AL}$ of low-grade laterites is considered as a promising method which efficiently recovers $\mathrm{Ni}$ and Co with low cost due to milder leaching conditions. The majority of studies were carried out using sulfuric acid as lixiviant and fewer tested nitric and hydrochloric acid [1,6-8]. More recent studies comparing the performance of $\mathrm{HCl}$ and $\mathrm{H}_{2} \mathrm{SO}_{4}$, under atmospheric conditions indicated that hydrochloric acid is more effective for both nickel and cobalt extraction $[4,8]$. However, AL using hydrochloric acid as a lixiviant results in high iron and magnesium dissolution which is related to high acid consumption and requires a complex purification treatment.

$\mathrm{HL}$ is a well-known process due to the numerous applications for the treatment of copper, uranium, and gold ores, and requires low investment and operating costs. However, $\mathrm{Ni}$ and Co recoveries by $\mathrm{HL}$ are relatively low compared with leaching in stirred reactors $[9,10]$. Studies were carried out evaluating the bio-hydrometallurgical HL of laterites using organic acids, citric acid, and oxalic acid, or using heterotrophic micro-organisms which metabolize organic compounds and excrete organic acids, namely carboxylic acids. These microorganisms should be tolerant to metal mixtures [11,12].

The majority of studies aim at optimizing the conditions of atmospheric leaching, in order to maximize Ni and Co extraction, and fewer deal with the purification of pregnant leach solution (PLS), which has low concentrations of $\mathrm{Ni}(0.8-3.3 \mathrm{~g} / \mathrm{L})$ and $\mathrm{Co}(0.05-0.2 \mathrm{~g} / \mathrm{L})$ and high concentrations of the major elements, mainly Fe (13-37 g/L) and Mg $(8-40 \mathrm{~g} / \mathrm{L})[13,14]$. The main processes for PLS purification include precipitation, solvent extraction, and ion exchange. Precipitation takes place when the chemical species exceed their limit of solubility by changing the solution $\mathrm{pH}$ or temperature, or by adding a reagent [15]. Solvent extraction presents high selectivity and involves mixing of PLS with an organic phase; the resulting emulsion is allowed to separate, and the valuable metals are transferred to the organic phase $[11,16,17]$. The use of ion-exchange media, such as resins, zeolite, and active carbon, in order to exchange cations or anions from a solution, presents high recoveries and is environmentally friendly, but these media have limited efficiency in mixed stream solutions [15].

The high ferric iron content constitutes the major impurity in the PLS produced by the atmospheric acid leaching of laterites [18]. The removal of iron from PLS involves a difficult and costly step. Moreover, it often results in important $\mathrm{Ni}$ and Co losses (5-20\%) [19]. Iron removal has been extensively studied in zinc industry in the early 1960s and several techniques have been developed for iron precipitation as jarosite, goethite and hematite [19]. The majority of studies for the purification of sulphate leach liquors involve the addition of limestone or calcium hydroxide, in order to increase the $\mathrm{pH}$ of the solution, so that metal hydroxides are formed and precipitate $[16,20,21]$. Ni and $\mathrm{Fe}$ hydroxides precipitate at different $\mathrm{pH}$, however it is difficult to avoid co-precipitation of Ni during the removal of Fe. Nickel co-precipitation takes place due to its adsorption on the surface of iron hydroxides or substitution in the precipitates. The temperature increase affects the stability and the crystallization of the precipitates. For these reasons the process conditions such as $\mathrm{pH}$, temperature, and duration of precipitation have serious impact on the properties of the precipitates and the potential $\mathrm{Ni}$ and Co losses [18,22].

Some steps of the purification treatment of the hydrochloric acid leach solutions are yet to be thoroughly investigated. Filippou and Choi [23] evaluated the step of iron precipitation by adding sodium hydroxide or urotropin at $100{ }^{\circ} \mathrm{C}$. However, the formation of various allotropes of $\mathrm{FeOOH}$ made the step of solid/liquid separation difficult and resulted in high losses of the other metals. Increasing the $\mathrm{pH}$ to $5.5 \mathrm{improved}$ solid/liquid separation, but caused higher losses of $\mathrm{Ni}$ and $\mathrm{Co}$ [24]. Beukes et al. [24] suggested that nickel and cobalt adsorption on the surface of iron oxides (goethite and hematite) is dependent on the presence of precipitates and not on their quantity. The researchers focused on solvent extraction processes due to the difficulties which occurred upon the precipitation of iron oxides. Many neutral extractants such as tri- $n$-butyl phosphate (TBP), tri- $n$-octylphosphine oxide (TOPO), amines, and mixtures of them were tested, but effective iron removal requires many steps 
due to the absence of an adequate "salting out agent". In a solution with concentration of $200 \mathrm{~g} / \mathrm{L}$ $\mathrm{MgCl}_{2}$, the removal of iron (40 $\mathrm{g} / \mathrm{L}$ ) was equal to $99.4 \%$ using TBP and methylisobutyl ketone (MIBK) with some losses of Co [11]. Demopoulos et al. [25] tested hydrolytic distillation for the precipitation of ferric iron as $\mathrm{Fe}_{2} \mathrm{O}_{3}$ and the recovery of $\mathrm{Cl}^{-}$as $\mathrm{HCl}$. Nickel and cobalt were precipitated as oxides at an operating temperature of $\sim 170^{\circ} \mathrm{C}$. Zhang et al. [2] applied hydrolytic distillation on synthetic laterite-leaching solutions and showed that $95.5 \%$ of iron was removed as hematite, $94 \%$ of $\mathrm{Ni}$ and Co remained in the aqueous phased as soluble chlorides, and excess $\mathrm{HCl}$ was distilled with a final recovery in the order of $77.9 \%$. The removal of $\mathrm{Mn}$ and $\mathrm{Mg}$ constitutes another significant challenge for PLS purification treatment $[15,17]$.

In this study, a counter-current leaching (CCL) scheme was evaluated for the $\mathrm{HCl}$ leaching of a saprolitic ore. The CCL mode of operation was adopted in order to maintain the co-dissolution of Fe at low levels and obtain satisfactory extraction of $\mathrm{Ni}$ and $\mathrm{Co}$, while operating at high pulp densities close to the industrial practice. The proposed flowchart for the treatment of PLS consists of a series of simple precipitation steps.

\section{Materials and Methods}

\subsection{Investigated Flowchart}

A conceptual flowchart illustrating the main steps of the $\mathrm{HCl}$ leaching process, which were investigated in the framework of this study, is shown in Figure 1. In this flowchart, the first step concerns the leaching of laterite ore. The next step (precipitation of trivalent metals) involves the removal of iron and other trivalent metals, e.g., $\mathrm{Cr}$ (III), $\mathrm{Al}(\mathrm{III})$, etc., in the form of hydroxides, using $\mathrm{MgO}$ as a neutralization agent and maintaining the $\mathrm{pH}$ at relatively acidic conditions, i.e., 3.5. The solution resulting from this treatment step contains all divalent metals, including $\mathrm{Ni}, \mathrm{Co}, \mathrm{Mn}, \mathrm{Mg}$, and $\mathrm{Ca}$. The following step aims primarily at the separation of alkaline earths, $\mathrm{Mg}$ and $\mathrm{Ca}$, from the other divalent metals by increasing the $\mathrm{pH}$ close to 9. This step is combined with the oxidation of $\mathrm{Mn}(\mathrm{II})$ to the tetravalent state, $\mathrm{Mn}(\mathrm{IV})$, and, for this reason, is denoted as alkaline oxidation (AO) in the flowchart of Figure 2. $\mathrm{Mg}$ and $\mathrm{Ca}$ remain in the aqueous phase, while $\mathrm{Ni}, \mathrm{Co}$, and $\mathrm{Mn}$ are recovered in the form of a solid residue containing $\mathrm{Ni}(\mathrm{OH})_{2}, \mathrm{Co}(\mathrm{OH})_{2}$, and $\mathrm{MnO}_{2}$. The next step, acidic dissolution (AD), involves the acidic treatment of the solid residue, in order to enable the selective dissolution of $\mathrm{Ni}$ and $\mathrm{Co}$, given that the high-valence $\mathrm{Mn}$ is expected to remain in the solid state.

The aqueous solution of the AO step contains mainly $\mathrm{Mg}, \mathrm{Ca}$, and $\mathrm{Cl}^{-}$anions. Calcium can be removed from these solutions via precipitation as $\mathrm{CaSO}_{4} \cdot \mathrm{xH}_{2} \mathrm{O}[26,27]$. The final stream containing $\mathrm{Mg}$ and $\mathrm{Cl}$ can be treated by pyrohydrolysis. By this process, it is possible to regenerate $\mathrm{HCl}$, which is recycled in the leaching step, producing $\mathrm{MgO}$.

As seen in Figure 1, the investigated flowchart involves a series of successive precipitation steps. Initial thermodynamic calculations were carried out using Visual Minteq software [28] to identify the optimum $\mathrm{pH}$ ranges, which could allow the selective separation of impurities, through precipitation of metal hydroxides, from the valuable metals. For this reason, the model was run using fixed $\mathrm{pH}$ values in the whole $\mathrm{pH}$ range between 0 and 14 . The following metal hydroxides were considered as possible precipitates: ferrihydrite $(\mathrm{Fh}), \mathrm{Al}(\mathrm{OH})_{3}, \mathrm{Cr}(\mathrm{OH})_{3}, \mathrm{Ni}(\mathrm{OH})_{2}, \mathrm{Co}(\mathrm{OH})_{2}$, pyrochroite $\left(\mathrm{Mn}(\mathrm{OH})_{2}\right)$ or pyrolusite $\left(\mathrm{MnO}_{2}\right)$, brucite $\left(\mathrm{Mg}(\mathrm{OH})_{2}\right)$, and portlandite $\left(\mathrm{Ca}(\mathrm{OH})_{2}\right)$. 


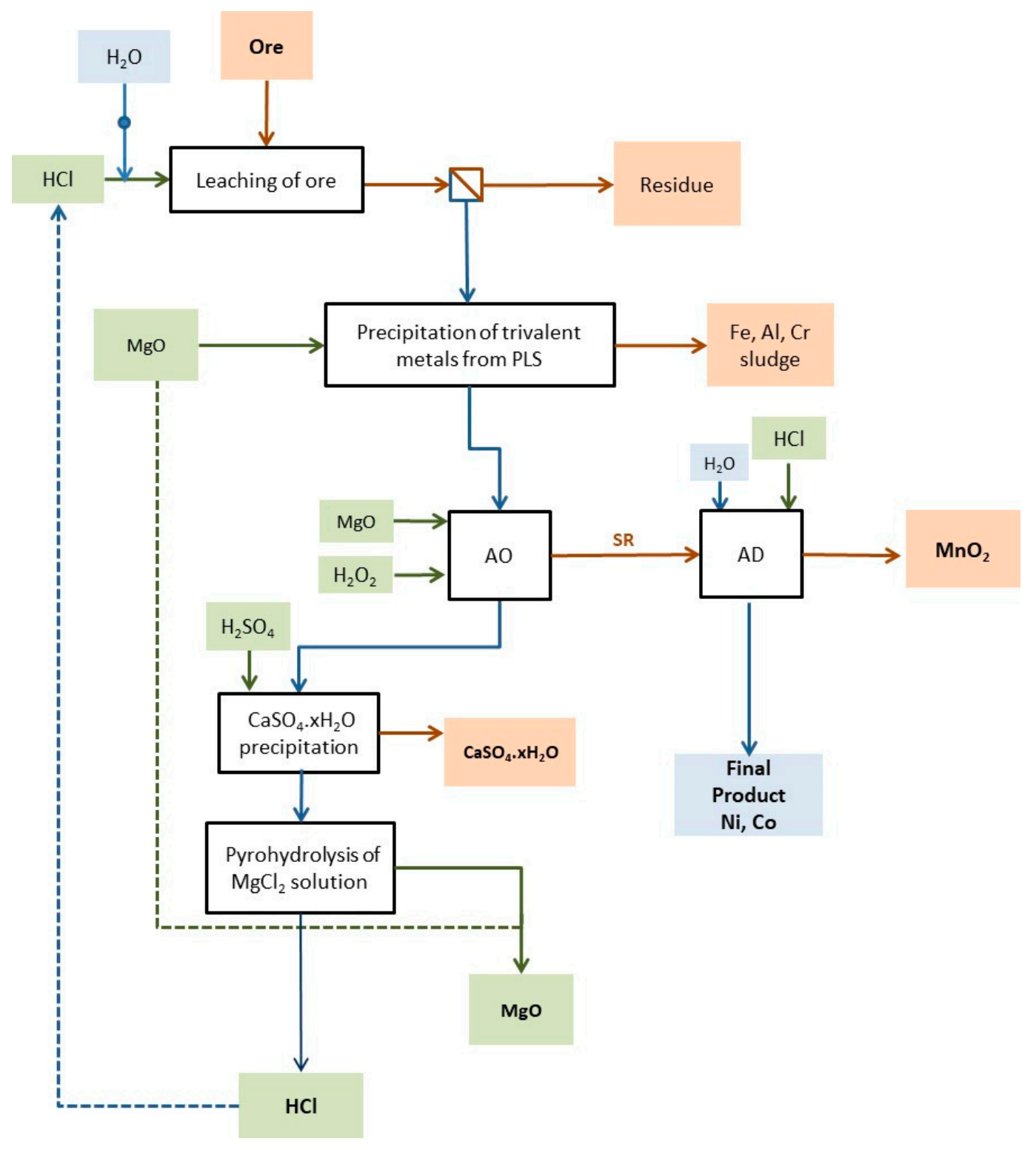

Figure 1. The main steps of the investigated $\mathrm{HCl}$ leaching process for the treatment of laterite ores.

\subsection{Materials}

The saprolitic laterite used in this study was collected from Larco deposits in the area of Kastoria (northern Greece). The sample (50 kg) was homogenized, ground using vibration milling for $10 \mathrm{~min}$, and the particle size of the working sample was under $74 \mu \mathrm{m}$.

The chemical composition of the laterite is given in Table 1. For the elemental analysis, the representative subsample of the ore was subjected to digestion with aqua regia, and the resulting solution was analyzed using atomic absorption spectroscopy (AAS). As seen in Table 1, the laterite contained nickel $0.88 \%$, cobalt $0.06 \%$, iron $22.42 \%$, and magnesium $7.58 \%$. The X-ray diffraction (XRD) analysis showed that the ore consisted mainly of quartz, goethite, calcite, and lizardite $\left((\mathrm{Mg}, \mathrm{Al})_{3}\left[(\mathrm{Si}, \mathrm{Fe})_{2} \mathrm{O}_{5}\right](\mathrm{OH})_{4}\right)$. Reagents used for the leaching experiments and for the purification of PLS were $\mathrm{HCl}$ (Chem-Lab, Zedelgem, Belgium), $\mathrm{Mg}(\mathrm{OH})_{2}$ (Sigma Aldrich, Tokyo, Japan), $\mathrm{H}_{2} \mathrm{O}_{2}$ (Sigma Aldrich, Steinheim, Germany), and $\mathrm{NaOH}$ (Sigma Aldrich, Steinheim, Germany). 


\subsection{Leaching of Laterite Ore}

The atmospheric leaching experiments were conducted using glass reactors of 1000-mL capacity, equipped with a heating mantle connected with a temperature controller, and mechanically agitated with a Heidolph Mixer at $500 \mathrm{rpm}$. An initial series of tests were carried out using one leaching step and investigating the effect of $\mathrm{HCl}$ concentration $(1$ to $4 \mathrm{M})$, temperature $\left(65-90^{\circ} \mathrm{C}\right)$, and pulp density $(10-30 \% w / v)$. A second series of tests were conducted using two leaching steps in a counter-current mode of operation (counter-current leaching, $\mathrm{CCL}$ ). The experimental procedure for the simulation of CCL operation is shown in Figure 2. It should be noted that it is difficult to simulate the steady-state conditions of a continuous CCL system using batch experiments.

Table 1. Chemical analysis of ore sample.

\begin{tabular}{cc}
\hline Main Elements & $\%$ \\
\hline $\mathrm{Fe}$ & 22.42 \\
$\mathrm{Ni}$ & 0.88 \\
$\mathrm{Mg}$ & 7.58 \\
$\mathrm{Co}$ & 0.06 \\
$\mathrm{Ca}$ & 2.78 \\
$\mathrm{Al}$ & 0.48 \\
$\mathrm{Cr}$ & 0.19 \\
$\mathrm{Mn}$ & 0.42 \\
$\mathrm{Si}$ & 0.04 \\
Insoluble $^{(\mathrm{a})}$ & 24.27 \\
Loss on ignition $^{(\mathrm{b})}$ & 13.22 \\
\hline
\end{tabular}

(a) Solid residue of the aqua regia digestion; (b) weight loss after heating at $1000{ }^{\circ} \mathrm{C}$ for 30 minutes.

In the leaching step 1a (Figure 2), $300 \mathrm{~g}$ of ore was treated with $1000 \mathrm{~mL}$ of $2 \mathrm{M} \mathrm{HCl}$ at $80{ }^{\circ} \mathrm{C}$ for six hours. Due to the relatively low extraction of $\mathrm{Ni}$ and Co during this step, the resulting solid residue was leached again with $1000 \mathrm{~mL}$ of $2 \mathrm{M} \mathrm{HCl}$ under similar conditions (step 1b). The second acid attack was able to dissolve an additional amount of $\mathrm{Ni}$ and $\mathrm{Co}$ from the residue, but the solution contained also high concentration of the undesirable iron. To enable re-precipitation of dissolved Fe, the leaching solution from step $1 \mathrm{~b}$ was used for the treatment of fresh ore (step $1 \mathrm{a}^{\prime}$ ). The iron-free solution emanating from step $1 \mathrm{a}^{\prime}$ was enriched in Ni and Co and constituted the pregnant solution, which was used in the subsequent PLS purification steps. The leach solution LS-1a from step 1a was not considered as representative of the PLS composition of a continuous CCL operation.

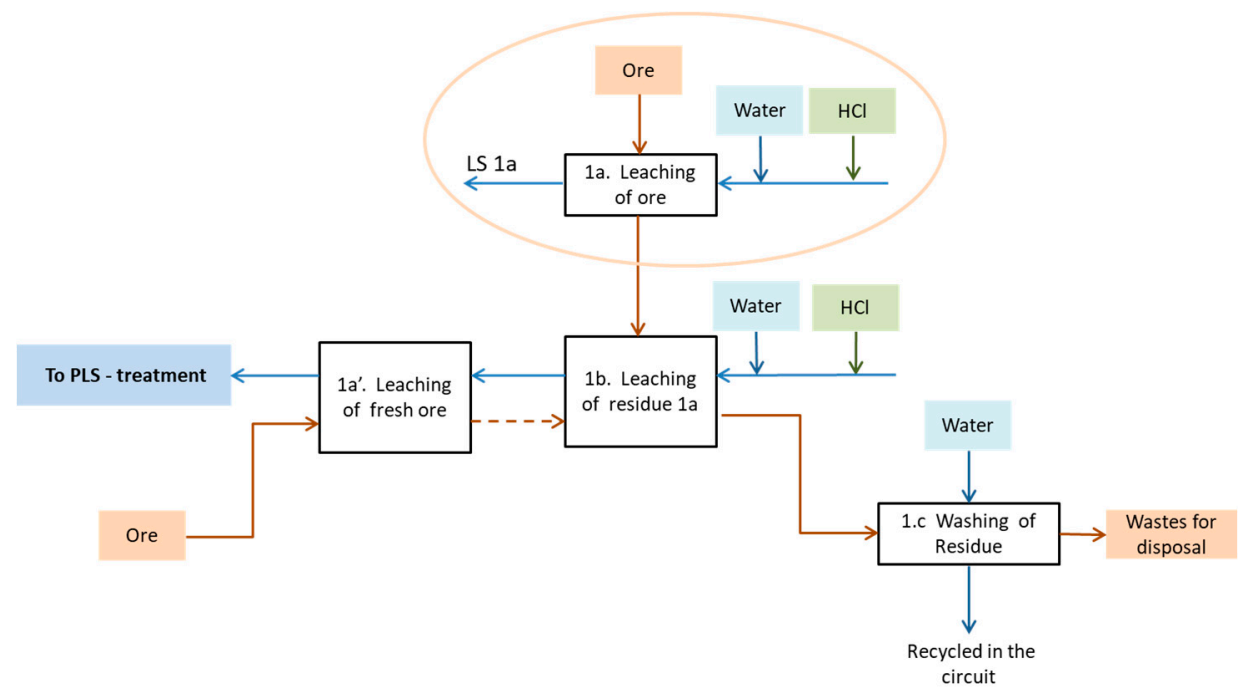

Figure 2. The experimental procedure for the simulation of counter-current leaching (CCL) operation during $\mathrm{HCl}$ leaching of the laterite ore. 
The solid residues produced from step $1 \mathrm{~b}$ were washed using a solid/liquid (S/L) ratio of $30 \%$ (step 1c). A representative sample of the washed solids was subjected to the EN12457.02 standard leaching test procedure $(\mathrm{L} / \mathrm{S}=10 \mathrm{~L} / \mathrm{kg})$ [29]. The test was carried out in duplicate.

\subsection{Treatment of Pregnant Solution}

\subsubsection{Experiments with the PLS of One-Step Leaching}

The initial determination of optimum conditions for the treatment of pregnant solution was carried out using the PLS of the one-step leaching of ore at $10 \%$ pulp density, temperature of $80^{\circ} \mathrm{C}$, and $2 \mathrm{M} \mathrm{HCl}$ with six hours of treatment time.

The main parameter investigated for the precipitation of trivalent metals step was the final precipitation $\mathrm{pH}$. Four $\mathrm{pH}$ values were tested, namely $2.5,3,3.5$, and 4 . The tests were carried out using $50 \mathrm{~mL}$ of PLS and adding dropwise a $\mathrm{Mg}(\mathrm{OH})_{2}$ slurry, $10 \% \mathrm{w} / v$, to obtain the predetermined final $\mathrm{pH}$ value. The suspension was agitated for $2 \mathrm{~h}$ in an orbital shaker (150 rpm) and, after the end of the experiment, centrifugation (Hettich Universal 320A centrifuge) took place in order to separate the solution from the solids. The supernatant was filtered through a $0.45-\mu \mathrm{m}$ membrane filter and analyzed for $\mathrm{Fe}, \mathrm{Ni}, \mathrm{Co}, \mathrm{Mg}, \mathrm{Mn}, \mathrm{Cr}, \mathrm{Al}$, and $\mathrm{Si}$ using atomic absorption spectroscopy with flame emission.

The AO treatment was then carried out in the solution which was produced after the precipitation of $\mathrm{Fe}, \mathrm{Al}$, and $\mathrm{Cr}$ at $\mathrm{pH}$ 3.5. The main parameter which was investigated during $\mathrm{AO}$ was the amount of the added $\mathrm{H}_{2} \mathrm{O}_{2}$. The experiments were carried out by adding $\mathrm{H}_{2} \mathrm{O}_{2}(1 \%, 2 \%, 5 \%$, or $10 \% \mathrm{w} / v)$ to $50 \mathrm{~mL}$ of the purified PLS. The $\mathrm{pH}$ was increased from 3.5 to 9.0 by adding $\mathrm{NaOH}$ solution $(1 \mathrm{M})$. The tests were conducted in 250-mL conical flasks at room temperature, using a magnetic stirrer for agitation, and the total duration was $1.5 \mathrm{~h}$. At the end of treatment, the suspensions were filtered and the aqueous solutions were analyzed for $\mathrm{Ni}, \mathrm{Co}, \mathrm{Mg}, \mathrm{Mn}, \mathrm{Ca}$, and $\mathrm{Al}$ using atomic absorption spectroscopy with flame emission.

The solid residue, produced by the AO process, was treated by mixing with $50 \mathrm{~mL}$ of distilled water and adjusting the $\mathrm{pH}$ using $2 \mathrm{M} \mathrm{HCl}$. The effect of $\mathrm{pH}$ on the recovery of $\mathrm{Ni}, \mathrm{Co}, \mathrm{Mn}$, and $\mathrm{Mg}$ was investigated by conducting dissolution tests at $\mathrm{pH}$ values equal to 1,3 , and 6 . The tests were conducted in 100-mL conical flasks at room temperature, using a magnetic stirrer for agitation, and the total duration was $1 \mathrm{~h}$.

In order to enrich the concentrations of $\mathrm{Ni}$ and $\mathrm{Co}$ and remove the remaining $\mathrm{Mg}$ and $\mathrm{Mn}$, the $\mathrm{AO}$ and $\mathrm{AD}$ steps were repeated twice. The $\mathrm{AO}$ was conducted using $5 \mathrm{wt} . \% \mathrm{H}_{2} \mathrm{O}_{2}$ and the AD was carried out decreasing the $\mathrm{pH}$ to 0.8 . The solid residues from AD-2 were characterized by SEM and energy-dispersive X-ray spectroscopy (EDS) analysis.

\subsubsection{Experiments with the PLS of CCL}

The parameters investigated during the treatment of PLS from CCL included the final $\mathrm{pH}$ of the precipitation of trivalent metals step and the $\mathrm{pH}$ of the $\mathrm{AD}$ step.

For the pyrohydrolysis treatment, the performance was estimated using the HSC Chemistry software (version 7.6.1). The main objective of using the HSC software was to determine the temperature required in order to recover the $\mathrm{HCl}$ in the gas phase and $\mathrm{MgO}$ as a solid precipitate.

\subsection{Analytical Methods}

The aqueous samples were analyzed using AAS with flame emission (Perkin Elmer 2100, Wellesley, MA, USA) and inductively coupled plasma mass spectrometry (ICP-MS; $X$ series Thermo Fisher Scientific, Waltham, MA, USA). Divalent Fe(II) was determined using the phenanthroline method. The morphology of the solids was also examined by scanning electron microscopy (SEM) using a JEOL 6380LV Microscope (JEOL, Tokyo, Japan). Chemical analysis of observed grains was carried out using an Oxford INCA energy-dispersive spectrometer (EDS) (Oxford Instruments, Abingdon, UK) connected to SEM. Centrifugation was carried out in a Hettich Centrifuge, model Universal 320A. 
The XRD analysis was performed using a Bruker D8-Focus powder diffractometer (Bruker, Karlsruhe, Germany), with nickel-filtered CuK $\alpha$ radiation $(\lambda=1.5405 \AA)$.

\section{Results}

\subsection{Leaching Experiments}

\subsubsection{Initial One-Step Leaching Tests ( $10 \%$ Pulp Density)}

The results of the one-step leaching tests are presented in Table 2. High $\mathrm{HCl}$ concentration $(4 \mathrm{M})$ at $80{ }^{\circ} \mathrm{C}$ and $\mathrm{S} / \mathrm{L} 10 \%$ resulted in $98 \%$ and $96 \%$ extraction of $\mathrm{Ni}$ and $\mathrm{Co}$, respectively. Increase of the temperature from 65 to $90{ }^{\circ} \mathrm{C}$ had a positive effect on the extraction of both $\mathrm{Ni}$ and Co, whereby $\mathrm{Ni}$ increased from $75.5 \%$ to $94.4 \%$ and Co from $76.8 \%$ to $88.6 \%$. Higher ratios of S/L resulted in a decrease of extraction percentage of all elements, i.e. $\mathrm{Ni}, \mathrm{Co}, \mathrm{Fe}$, and to a lesser extent $\mathrm{Mg}$ (see Table 2). Based on leaching results, it was deduced that hydrochloric acid in higher ratios of $\mathrm{S} / \mathrm{L}$ resulted in lower $\mathrm{Fe}$ co-dissolution. In order to enrich the PLS in Ni and Co and preserve the low Fe co-dissolution, it was decided to investigate the performance of a CCL scheme. It should be noted that the major part of dissolved $\mathrm{Fe}$, i.e., more than $98 \%$, was in the trivalent state.

\subsubsection{Counter-Current Leaching of Ore (30\% Pulp Density)}

The CCL treatment of ore was carried out using 30\% pulp density. The final extraction of metals and the concentrations in the PLS are shown in Tables 3-6. As seen in Table 3, leaching of the ore at high pulp density (30\%) resulted in very low dissolution of $\mathrm{Fe}, 1.62 \%$, but $\mathrm{Ni}$ and Co extraction was also low- $49.29 \%$ and $43.03 \%$, respectively (step 1a). When the residue was treated with fresh $\mathrm{HCl}$ (step 1b), extraction of $\mathrm{Ni}$ and $\mathrm{Co}$ increased and reached $84.06 \%$ and $80.52 \%$, respectively, but the second treatment step resulted also in increased dissolution of Fe to $31.64 \%$. The leaching solution from step $1 \mathrm{~b}$ was used for the treatment of fresh ore (step $1 \mathrm{a}^{\prime}$, Figure 2). It can be seen that almost all Fe was extracted during step $1 \mathrm{~b}$ precipitated, indicated by the negative extraction percentage $(-29.46 \%)$ shown in Table 3. The composition of all leaching solutions is presented in Table 4. As seen in this table, the concentration of Fe dropped substantially from 20.19 (step 1b) to $0.38 \mathrm{~g} / \mathrm{L}$ (step 1a'). The concentration of $\mathrm{Ni}$ increased from 0.917 to $1.46 \mathrm{~g} / \mathrm{L}$, while that of Co increased from 0.066 to $0.113 \mathrm{~g} / \mathrm{L}$.

From the elemental composition of leaching solutions, the residual acidity was calculated. It can be seen that all the acidity of the solution in step 1a was consumed, mainly from the dissolution of $\mathrm{Mg}$ and $\mathrm{Ca}$. The solid residue treated in step $\mathrm{b}$ contained lower amounts of $\mathrm{Ca}$ and $\mathrm{Mg}$ and, for this reason, the corresponding minerals did not consume all the acidity of the fresh $\mathrm{HCl}$ solution. In the solution of step $1 \mathrm{~b}$, the residual acidity was high, i.e., $0.088 \mathrm{M}$, and this was the reason for the observed relatively high dissolution of Fe in step $1 \mathrm{~b}$. When this solution was used for the treatment of fresh ore in step 1a', the residual acidity was again consumed by $\mathrm{Ca}$ and $\mathrm{Mg}$, while the dissolved Fe precipitated.

Table 2. Metal extraction (\%) from the saprolitic ore after six hours leaching with $\mathrm{HCl}$.

\begin{tabular}{ccccccc}
\hline HCl Molarity & \multirow{2}{*}{$\begin{array}{c}\text { Temperature }{ }^{\circ} \mathbf{C} \\
\mathbf{M n n y y y y}\end{array}$} & & $\begin{array}{c}\text { Solid/Liquid (S/L) Ratio } \\
\text { \% w/v }\end{array}$ & \multicolumn{4}{c}{ Extraction (\%) } \\
\cline { 4 - 7 } & 80 & 10 & $\mathbf{N i}$ & $\mathbf{C o}$ & $\mathbf{F e}$ & $\mathbf{M g}$ \\
\hline 1 & 80 & 10 & 41.1 & 40.5 & 3.0 & 100.0 \\
2 & 80 & 10 & 79.3 & 84.3 & 54.0 & 100.0 \\
3 & 80 & 10 & 95.9 & 96.5 & 93.7 & 100.0 \\
4 & 65 & 10 & 97.9 & 96.0 & 97.5 & 100.0 \\
2 & 90 & 10 & 75.5 & 76.8 & 39.4 & 100.0 \\
2 & 80 & 20 & 94.4 & 88.6 & 56.7 & 100.0 \\
2 & 80 & 30 & 59.1 & 54.1 & 11.9 & 100.0 \\
& & & 45.1 & 39.8 & 1.5 & 77.4 \\
\hline
\end{tabular}




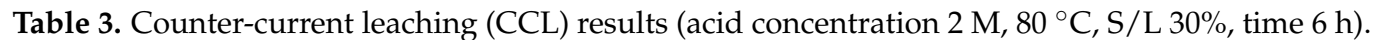

\begin{tabular}{ccccccc}
\hline Step & $\mathbf{p H}$ & Ni (\%) & Co (\%) & Fe (\%) & Mg (\%) & Mn (\%) \\
\hline 1a Leaching of ore & 1.04 & 49.29 & 43.03 & 1.62 & 75.60 & 41.04 \\
\hline $\begin{array}{c}\text { 1b Leaching of 1a step } \\
\text { residue with fresh acid }\end{array}$ & 34.77 & 37.89 & 30.02 & 32.60 & 37.37 \\
\hline 1a+1b & 84.06 & 80.92 & 31.64 & 108.20 & 78.41 \\
\hline $\begin{array}{c}\text { 1a' Leaching of fresh } \\
\text { ore pregnant leach } \\
\text { solution (PLS) }\end{array}$ & 1.31 & 20.59 & 26.86 & -29.46 & 33.41 & 27.49 \\
\hline $1 a^{\prime}+1 b$ & 55.36 & 64.75 & 0.56 & 66.01 & 64.86 \\
\hline
\end{tabular}

Table 4. Composition of PLS streams obtained by the CCL (steps in Figure 2).

\begin{tabular}{ccccccc}
\hline & \multicolumn{2}{c}{ Step 1a } & \multicolumn{2}{c}{ Step 1b } & \multicolumn{2}{c}{ Step 1a' } \\
\hline Concentration & $\mathbf{g} / \mathbf{L}$ & $\mathbf{m o l} / \mathbf{L}$ & $\mathbf{g} / \mathbf{L}$ & $\mathbf{m o l} / \mathbf{L}$ & $\mathrm{g} / \mathbf{L}$ & $\mathbf{m o l} / \mathbf{L}$ \\
\hline $\mathrm{Cl}^{-}$ & & 2.000 & & 2.000 & & 2.000 \\
$\mathrm{Fe}^{+3}$ & 1.09 & 0.019 & 20.19 & 0.361 & 0.380 & 0.007 \\
$\mathrm{Cr}^{+3}$ & 0.019 & 0.000 & 0.063 & 0.001 & 0.017 & 0.0003 \\
$\mathrm{Al}^{+3}$ & 0.314 & 0.012 & 0.391 & 0.014 & 0.526 & 0.019 \\
$\mathrm{Ni}^{+2}$ & 1.3 & 0.022 & 0.917 & 0.016 & 1.460 & 0.025 \\
$\mathrm{Co}^{+2}$ & 0.075 & 0.001 & 0.066 & 0.001 & 0.113 & 0.002 \\
$\mathrm{Mn}^{+2}$ & 0.515 & 0.009 & 0.469 & 0.009 & 0.814 & 0.015 \\
$\mathrm{Mg}^{+2}$ & 17.2 & 0.708 & 8.1 & 0.333 & 15.70 & 0.646 \\
$\mathrm{Ca}^{+2}$ & 9.08 & 0.227 & 1.32 & 0.033 & 10.90 & 0.273 \\
$\mathrm{H}^{+}\left(^{*}\right)$ & & -0.030 & & 0.088 & & 0.001 \\
\hline
\end{tabular}

$\left(^{*}\right)$ Calculated based on electroneutrality.

\subsubsection{Washing of Leaching Solid Residues-Assessment of Environmental Quality}

Washing was applied to the solid residue of step $1 b$. The composition of wash water is shown in Table 5. As seen in the Table, the $\mathrm{pH}$ of the wash water was 1.60, suggesting that the high acidity of the leach solution in step $1 \mathrm{~b}$ which remained in the moisture of solid residue was not completely removed in the washing step.

Table 5. Composition of wash water (mg/L) obtained after washing of the leach solid residue (step 1c in Figure 2).

\begin{tabular}{ccccccccc}
\hline $\mathrm{pH}$ & $\mathbf{F e}$ & $\mathrm{Cr}^{+3}$ & $\mathbf{A l}^{+3}$ & $\mathbf{N i}^{+2}$ & $\mathbf{C o}^{+2}$ & $\mathbf{M n}^{+2}$ & $\mathbf{M g}^{+2}$ & $\mathbf{C a}^{+2}$ \\
\hline 1.60 & 1210 & 6.0 & 22 & 55 & 4 & 30 & 520 & 86 \\
\hline
\end{tabular}

The washed solid residue was subjected to EN12457.02 leaching, and the results are presented in Table 6. The leachate resulting from the mixing of deionized water with the solid residue showed that the leachability of $\mathrm{As}, \mathrm{Ba}, \mathrm{Cd}, \mathrm{Cu}, \mathrm{Pb}$, and Se met the criteria established by Directive 2003/33/EC for the acceptance of solid residue in landfills for inert waste. Dissolution of Zn was greater than the limits set for inert waste disposal, but satisfied the non-hazardous waste criterion. It was found that the solid residue contained a high leachable content of $\mathrm{Cr}$ and $\mathrm{Ni}$, which amounted to $142.6 \mathrm{mg} / \mathrm{kg}$ and $540.4 \mathrm{mg} / \mathrm{kg}$, respectively, and exceeded the limits set for non-hazardous waste disposal. It can also be seen that the residue retained a high level of acidity, since the $\mathrm{pH}$ of the leachate was 1.64.

The results suggest that the washing procedure, as applied during the laboratory tests, was not sufficient for the complete removal of acidity and of the leachable part of $\mathrm{Cr}$ and Ni. Thus, a multi-stage counter-current washing installation, combined with addition of alkalinity, was required in order to obtain a solid residue appropriate for safe environmental disposal. 


\subsubsection{Characterization of CCL Solid Residues}

\section{XRD Analysis}

The dried leach residues obtained after CCL were examined using XRD, and the patterns are shown in Figure 3. In comparison with the raw ore, the peaks of lizardite and calcite present in the ore disappeared after leaching with $\mathrm{HCl}$ in the solid residues of steps $1 \mathrm{~b}$ and $1 \mathrm{c}$. However, even though the peak of calcite also disappeared in the solid residue of step 1a', the peak of lizardite remained. Quartz and weaker goethite peaks remained in the $\mathrm{HCl}$ residues from all the steps of CCL process since these minerals are leached poorly in the acidic medium.

Table 6. Results of the EN 12457.02 ( $\mathrm{L} / \mathrm{S}=10 \mathrm{~L} / \mathrm{kg}$ ) leaching test for the washed CCL solid residue and comparison with the existing criteria for the acceptance of waste at inert non-hazardous and hazardous landfills (Directive 2003/33/EC).

\begin{tabular}{|c|c|c|c|c|c|}
\hline & \multirow{2}{*}{ Solution } & \multirow{2}{*}{ Sample } & \multicolumn{3}{|c|}{ Criteria for the Acceptance of Waste at Landfills } \\
\hline & & & Inert & Non-Hazardous & Hazardous \\
\hline \multirow{3}{*}{$\begin{array}{c}\mathrm{pH} \\
\text { Electrical conductivity } \\
(\mathrm{EC} ; \mathrm{mS} / \mathrm{cm})\end{array}$} & 1.64 & & & & \\
\hline & 15.29 & & & & \\
\hline & $\mathrm{mg} / \mathrm{L}$ & $\mathrm{mg} / \mathrm{kg}$ & & $\mathrm{mg} / \mathrm{kg}$ & \\
\hline As & $<0.006$ & $<0.06$ & 0.5 & 2 & 25 \\
\hline $\mathrm{Ba}$ & 0.165 & 1.659 & 20 & 100 & 300 \\
\hline $\mathrm{Cd}$ & 0.0006 & 0.006 & 0.04 & 1 & 5 \\
\hline $\mathrm{Cr}$ & 14.255 & 142.6 & 0.5 & 10 & 70 \\
\hline $\mathrm{Cu}$ & 0.130 & 1.305 & 2 & 50 & 100 \\
\hline $\mathrm{Ni}$ & 54.04 & 540.4 & 0.4 & 10 & 40 \\
\hline $\mathrm{Pb}$ & 0.010 & 0.104 & 0.5 & 10 & 50 \\
\hline Se & 0.0026 & 0.026 & 0.1 & 0.5 & 7 \\
\hline $\mathrm{Zn}$ & 0.662 & 6.627 & 4 & 50 & 200 \\
\hline
\end{tabular}

${ }^{*}$ Directive 2003/33/EC.

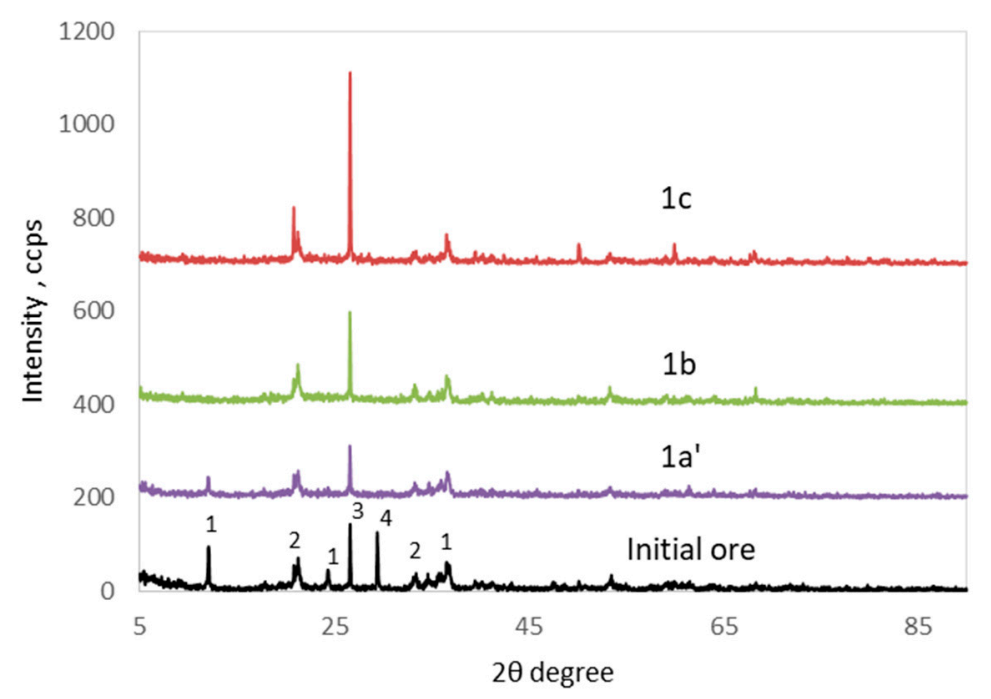

Figure 3. X-ray diffraction (XRD) patterns of leach residues from CCL in comparison with the pattern of the initial ore $\left(1\right.$, lizardite $\left.(\mathrm{Mg}, \mathrm{Al})_{3}\left[(\mathrm{Si}, \mathrm{Fe})_{2} \mathrm{O}_{5}\right](\mathrm{OH})_{4}\right) ; 2$, goethite $(\mathrm{FeOOH}) ; 3$, quartz; 4 , calcite).

\section{SEM Analyses}

The elemental composition of the saprolitic ore, before and after leaching, as derived by EDS analysis, is presented in Figure 4. In the examined grains of solid residue derived from step $1 \mathrm{~b}$ 
(Figure 4b), Ni and Co disappeared and the content of Fe and $\mathrm{Mg}$ decreased in comparison with the initial ore (Figure $4 \mathrm{a}$ ). The presence of $\mathrm{Cl}$ anions, related to the composition of leach solution, was also observed in the grains of residue obtained from step $1 \mathrm{a}^{\prime}$ (Figure 4c). The atomic ratio of major elements $(\mathrm{O} / \mathrm{Mg} / \mathrm{Si} / \mathrm{Fe})$ of the grain in Figure $4 \mathrm{c}$ was similar to the grain of the initial ore in Figure $4 \mathrm{a}$. However, the morphology of the grain in Figure $4 \mathrm{c}$ was very different, and this difference could be attributed to the presence of fine Fe precipitates on the surface of the grain. It should be reminded that approximately $19 \mathrm{~g} / \mathrm{L}$ Fe was removed from the aqueous phase via precipitation during ore leaching in step $1 a^{\prime}$.

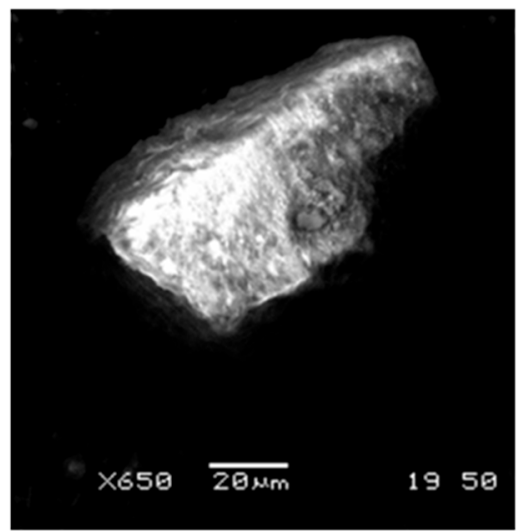

\begin{tabular}{cc}
\hline Element & $\begin{array}{c}\text { Atomic } \\
\%\end{array}$ \\
\hline O K & 69.46 \\
$\mathrm{Mg} \mathrm{K}$ & 6.08 \\
$\mathrm{~A} 1 \mathrm{~K}$ & 1.03 \\
$\mathrm{Si} \mathrm{K}$ & 5.71 \\
$\mathrm{Ca} \mathrm{K}$ & 0.47 \\
$\mathrm{Mn} \mathrm{K}$ & 0.06 \\
$\mathrm{Fe} \mathrm{K}$ & 16.14 \\
$\mathrm{Co} \mathrm{K}$ & 0.52 \\
$\mathrm{Ni} \mathrm{K}$ & 0.54
\end{tabular}

(a) Initial saprolitic ore

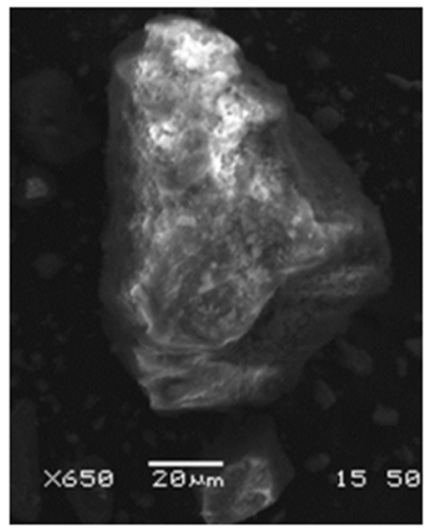

\begin{tabular}{cc}
\hline Element & $\begin{array}{c}\text { Atomic } \\
\%\end{array}$ \\
\hline $\mathrm{O} \mathrm{K}$ & 67.04 \\
$\mathrm{Mg} \mathrm{K}$ & 0.65 \\
$\mathrm{Si} \mathrm{K}$ & 24.86 \\
$\mathrm{Cl} \mathrm{K}$ & 3.43 \\
\hline
\end{tabular}

(b) Solid residue from $1 \mathrm{~b}$ step

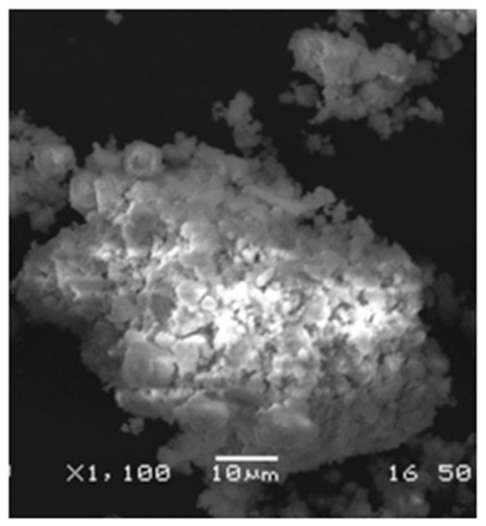

\begin{tabular}{cc}
\hline Element & $\begin{array}{c}\text { Atomic } \\
\%\end{array}$ \\
\hline $\mathrm{O} \mathrm{K}$ & 69.36 \\
$\mathrm{Mg} \mathrm{K}$ & 5.37 \\
$\mathrm{Cl} \mathrm{K}$ & 6.27 \\
$\mathrm{Si} \mathrm{K}$ & 6.91 \\
$\mathrm{Fe} \mathrm{K}$ & 12.10 \\
\hline
\end{tabular}

(c) Solid residue from 1a' step

Figure 4. SEM microphotographs and energy-dispersive X-ray spectroscopy (EDS) analyses of (a) initial grains, (b) grains after CCL step 1b, and (c) grains after CCL step 1a'.

\subsection{Precipitation of Trivalent Metals from Pregnant Leach Solution}

\subsubsection{Thermodynamic Calculations using Visual Minteq}

The thermodynamic calculations using VMinteq were carried out in order to identify the $\mathrm{pH}$ ranges, where precipitation of metal hydroxides took place for the separation of impurities from the valuable elements. As shown in Figure 5, precipitation of iron hydroxides (as ferrihydrite) was observed at $\mathrm{pH}$ values above 2. The increase in $\mathrm{pH}$ above 4 resulted in the precipitation of $\mathrm{Cr}$ and $\mathrm{Al}$ as $\mathrm{Al}(\mathrm{OH})_{3}$ and $\mathrm{Cr}(\mathrm{OH})_{3} \mathrm{~m}$ respectively. $\mathrm{Ni}$ and $\mathrm{Co}$ precipitated as $\mathrm{Ni}(\mathrm{OH})_{2}$ and $\mathrm{Co}(\mathrm{OH})_{2}$ at $\mathrm{pH}$ values higher than 7.5, while $\mathrm{Mg}$ precipitated as brucite at $\mathrm{pH}$ values higher than 9. Precipitation of $\mathrm{Ca}$ as portlandite occurred above $\mathrm{pH}$ 12. Based on the thermodynamic data of Visual Minteq, the solution that contained $0.073 \mathrm{M}$ of $\mathrm{Ca}$ was undersaturated with respect to lime. Also, according to the 
calculations, if $\mathrm{Mn}$ is divalent, it remains in solution in the whole range of $\mathrm{pH}$ values (Figure 5a), while, if tetravalent, it precipitates as pyrolusite $\left(\mathrm{MnO}_{2}\right)$ in the $\mathrm{pH}$ range of 4 to 9 (Figure $5 \mathrm{~b}$ ).

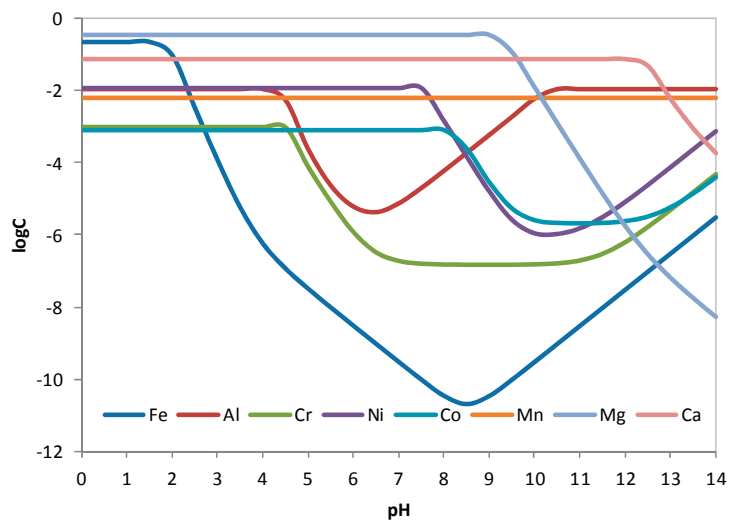

(a) Manganese assumed divalent

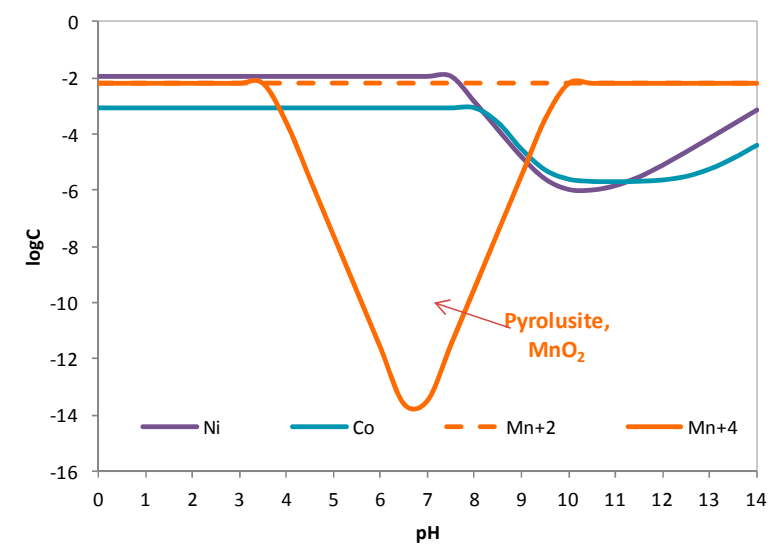

(b) Manganese assumed tetravalent

Figure 5. Thermodynamic calculations using Visual Minteq for the identification of optimum $\mathrm{pH}$ ranges for the selective precipitation of metals in the form of hydroxides.

\subsubsection{Experiments with the PLS Obtained after One-Step Leaching (10\% Pulp Density)}

Precipitation of Trivalent Metals from PLS

The treatment with $\mathrm{Mg}(\mathrm{OH})_{2}$ was conducted at four different target $\mathrm{pHs}(2.0,3.0,3.5$, and 4.0). The final volume of solution was increased due to the addition of $\mathrm{Mg}(\mathrm{OH})_{2}$ in the form of pulp $10 \%$ $w / v$. The percentage of metal removal was calculated by taking into consideration the factor of volume increase. As seen in Figure 6, the removal of Fe and $\mathrm{Cr}$ was higher than $99 \%$ above $\mathrm{pH} 3$. The removal percentage for $\mathrm{Al}$ was $97 \%$ at $\mathrm{pH} 3.5$ and increased to $99 \%$ at $\mathrm{pH} 4$. Co-precipitation (losses) of Ni and Co were estimated to be close to $0.6 \%$ and $1.2 \%$ for $\mathrm{Ni}$, and $4.5 \%$ and $7.6 \%$ for $\mathrm{Co}$ at $\mathrm{pH} 3.5$ and 4 , respectively.

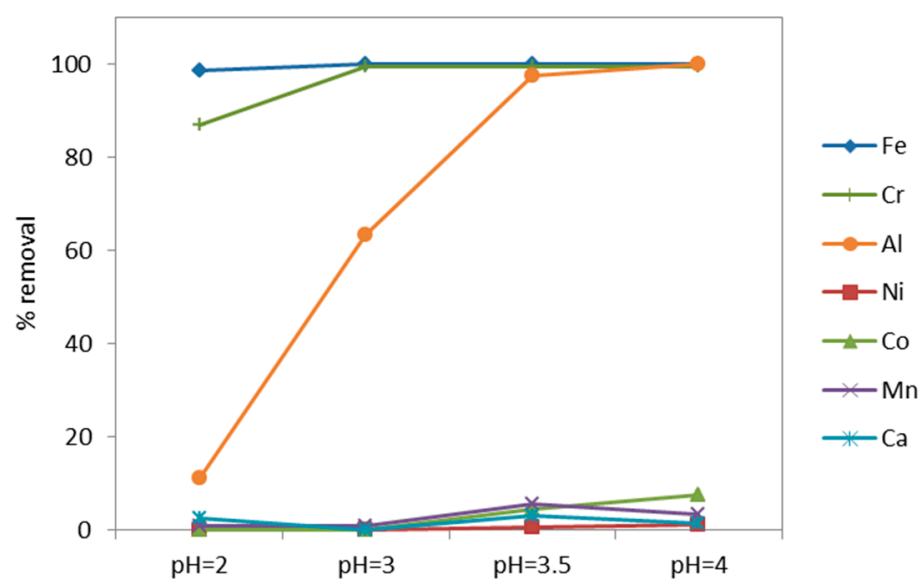

Figure 6. Effect of $\mathrm{pH}$ on metal removal during precipitation of trivalent metals from pregnant leach solution (PLS) obtained from one-step leaching test at 10\% pulp density.

Alkaline Oxidation (AO)

The $\mathrm{AO}$ treatment was applied to the solution produced after the precipitation of Fe with $\mathrm{Mg}(\mathrm{OH})_{2}$ at $\mathrm{pH}$ 3.5. The experiments were carried out using different doses of $\mathrm{H}_{2} \mathrm{O}_{2}$ ranging from $1 \%$ to $10 \%$ $w / v$ and increasing $\mathrm{pH}$ to 9 with the addition of $\mathrm{NaOH}(1 \mathrm{M})$. A control experiment without addition of $\mathrm{H}_{2} \mathrm{O}_{2}$ was also carried out at increased $\mathrm{pH}$ 9. In the control experiment, $\mathrm{Ni}$ and Co precipitation was higher than $99 \%$, but a relatively high percentage of Mn (12-20\%) remained in solution. When 
$\mathrm{H}_{2} \mathrm{O}_{2}$ was added, the precipitation of the three metals, $\mathrm{Ni}, \mathrm{Co}$, and $\mathrm{Mn}$, was almost complete. The dose of $\mathrm{H}_{2} \mathrm{O}_{2}$ had no effect on the final degree of precipitation. It should be noted that the color of the suspensions was different in the absence or presence of $\mathrm{H}_{2} \mathrm{O}_{2}$. Without $\mathrm{H}_{2} \mathrm{O}_{2}$, the color was green, while, in the presence of $\mathrm{H}_{2} \mathrm{O}_{2}$, it turned brown and this can be attributed to the presence of higher-valence Mn oxides.

According to the thermodynamic analysis of the system (see Figure 5a) precipitation of pure $\mathrm{Mn}^{+2}$ hydroxide (pyrochroite) was not expected to occur. However, it is known that $\mathrm{Ni}$ can form mixed hydroxides with many divalent and trivalent metals, including Mn(II) and Mn(III) [30]. According to Zhou et al., under anaerobic conditions, $\mathrm{Mn}^{+2}$ is incorporated into the structure of $\mathrm{Ni}(\mathrm{OH})_{2}$ hydroxide at all $\mathrm{Mn} / \mathrm{Ni}$ molar ratios [31]. Under aerobic conditions, $\mathrm{Mn}$ is oxidized to the $\mathrm{Mn}^{+3}$ state and layered double hydroxide (LDH) phases are formed. In the structure of LDH phases (similar to hydrotalcite), the layers have the approximate composition $\left[\mathrm{Ni}^{+2}{ }_{1-x} \mathrm{M}^{+3} x(\mathrm{OH})_{2}\right]^{+\mathrm{x}}$, and different anions are intercalated in the interlayer space for charge compensation and stability. Tetravalent cations like $\mathrm{Mn}^{+4}$ are not easily incorporated in the structure of $\mathrm{LDH}$ [30]. If $\mathrm{Mn}$ is oxidized in the +4 state, it will probably precipitate as pyrolusite $\left(\mathrm{MnO}_{2}\right)$ (see Figure $\left.5 b\right)$. These mechanisms could explain the removal of $\mathrm{Mn}$ together with $\mathrm{Ni}$, either with or without the addition of $\mathrm{H}_{2} \mathrm{O}_{2}$. If $\mathrm{Mn}$ (II) remains in solids, it is impossible to separate it from $\mathrm{Ni}$ and $\mathrm{Co}$ using the acidic treatment of $\mathrm{AO}$ solid residue.

Acid Dissolution (AD) of AO Solid Residue

Preliminary acid dissolution tests carried out at $\mathrm{pH} 3$ indicated that the highest selective dissolution of $\mathrm{Ni}$ with respect to $\mathrm{Mn}$ was obtained from the solid residues produced at $5 \%$ and $10 \% w / v \mathrm{H}_{2} \mathrm{O}_{2}$, without major differences between the two residues. For this reason, subsequent tests were conducted using the $\mathrm{AO}$ solid residues obtained after treatment with the use of $5 \% w / v \mathrm{H}_{2} \mathrm{O}_{2}$. The dissolution tests were carried out at different $\mathrm{pH}$ values in order to determine the effect of $\mathrm{pH}$ on the recovery of metals in the aqueous solution. The results are shown in Figure 7. According to the thermodynamic calculations (Figure 5b), at $\mathrm{pH} 6$, tetravalent $\mathrm{Mn}(\mathrm{IV})$ remained in the solids, while Ni and Co hydroxides were completely dissolved. However, the experimental results indicate that all metals remained in the solids at $\mathrm{pH}$ 6. As previously discussed, more complex hydroxides with low solubility, containing $\mathrm{Ni}, \mathrm{Co}$, and $\mathrm{Mn}$, are probably formed close to neutral $\mathrm{pH}$ values. When the $\mathrm{pH}$ was decreased from 6 to 1,95\% dissolution of $\mathrm{Ni}$ and $89 \%$ dissolution of Co were obtained. However, Mn was also re-dissolved up to a percentage of $47 \%$. Moreover, the aqueous solution contained high levels of Mg. A representative composition of AD aqueous stream was Ni 801, Co 51, Mn 194, and Mg $5564 \mathrm{mg} / \mathrm{L}$.

To enable the separation of $\mathrm{Mg}$ and $\mathrm{Mn}$ from $\mathrm{Ni}$ and $\mathrm{Co}$, a treatment scheme involving three successive cycles of $\mathrm{AO}$ and $\mathrm{AD}$ of the solid residue was examined. The results are presented in Figure 8. As seen in the figure, the removal of $\mathrm{Mg}$ and $\mathrm{Mn}$ from the final Ni/Co stream was very efficient with the three-stage treatment. However, the recovery of $\mathrm{Ni}$ and $\mathrm{Co}$ also decreased from $95 \%$ and $89 \%$ to $70 \%$ and $63 \%$, respectively, indicating certain losses during the successive treatment steps. 


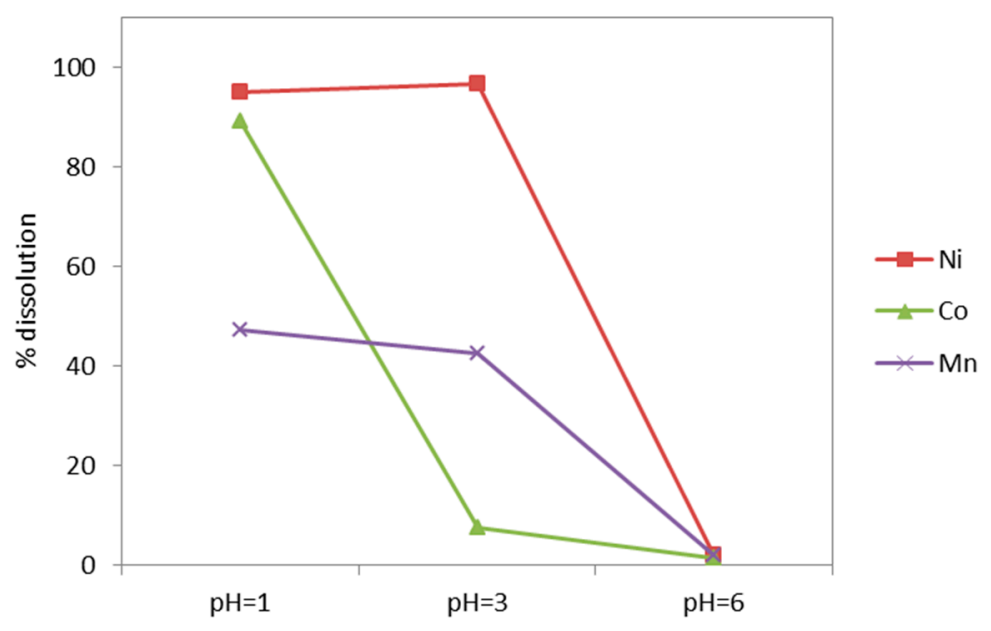

Figure 7. Effect of $\mathrm{pH}$ applied at the acidic dissolution (AD) step on dissolution of $\mathrm{Ni}, \mathrm{Co}$, and $\mathrm{Mn}$ from the solid residue of the alkaline oxidation (AO) step (with the use of $\mathrm{H}_{2} \mathrm{O}_{2} 5 \% \mathrm{w} / \mathrm{v}$ ).

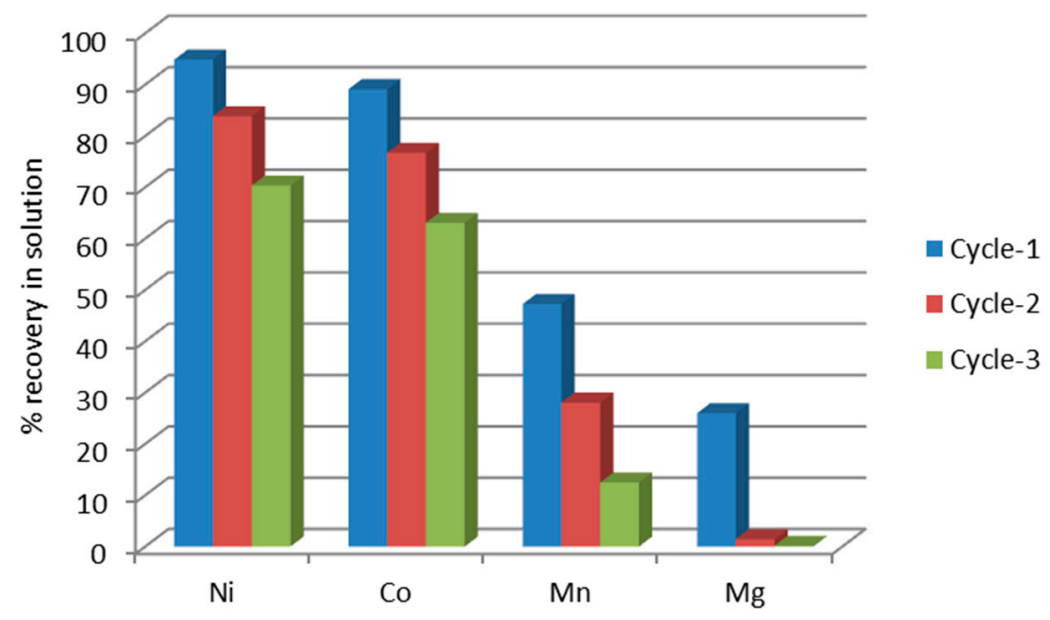

Figure 8. Percent recovery of $\mathrm{Ni}, \mathrm{Co}, \mathrm{Mn}$, and $\mathrm{Mg}$ in the aqueous solution, after three repetitive cycles of $\mathrm{AO}$ and $\mathrm{AD}$ steps.

\subsubsection{Experiments with the PLS of CCL ( $30 \% w / v$ Pulp Density)}

Precipitation of Trivalent Metals from CCL Pregnant Solution

The precipitation of trivalent metals from PLS produced by CCL was carried out with $\mathrm{Mg}(\mathrm{OH})_{2}$ at two $\mathrm{pH}$ values, 3.5 and 4. The percentage of precipitated metals is presented in Figure 9. At $\mathrm{pH}$ 3.5, Fe was $92.9 \%$, and some minor co-precipitation of $\mathrm{Ni}$ was noted $(4 \%)$, while no co-precipitation (losses) of Co was observed. The removal of $\mathrm{Cr}$ was also high (98.3\%), but the precipitation of $\mathrm{Al}$ was very low, only $15.9 \%$. When the precipitation was carried out at $\mathrm{pH} 4.0$ almost complete removal of $\mathrm{Al}$ was obtained and, for this reason, subsequent treatment steps were conducted using the PLS solution treated at $\mathrm{pH}$ 4.0. It should be mentioned that the filtration of the suspension was difficult due to the colloidal behavior of iron hydroxides; thus, S/L separation was carried out using centrifugation at $9000 \mathrm{rpm}$ for 20 minutes. 


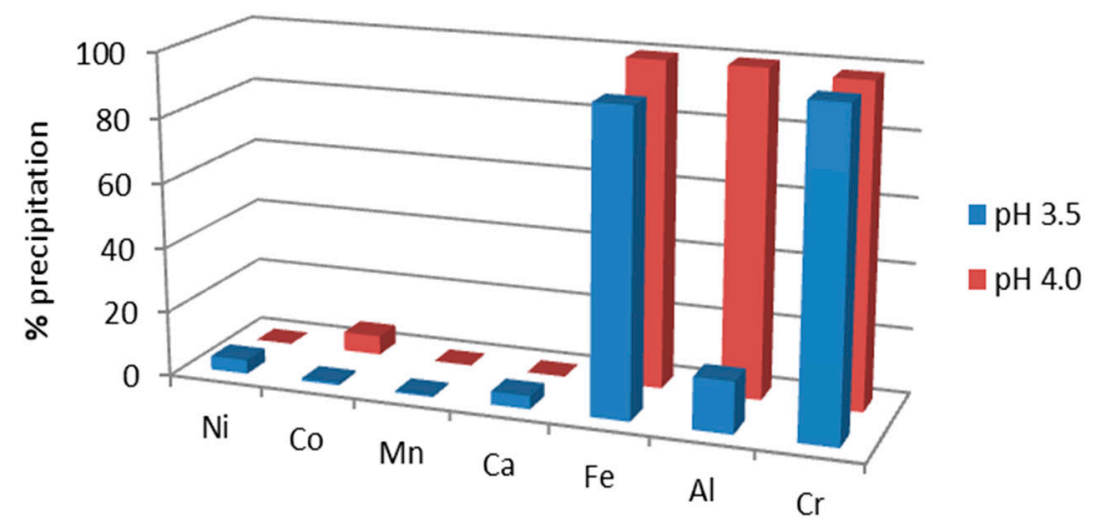

Figure 9. Metal removal (\%) from PLS during the precipitation of trivalent metals step.

Separation of $\mathrm{Mn}, \mathrm{Ca}$, and $\mathrm{Mg}$ from $\mathrm{Ni}$ and $\mathrm{Co}$ after Two-Stage AO and AD Treatment

In order to separate $\mathrm{Mn}, \mathrm{Ca}$, and $\mathrm{Mg}$ from the valuable metals, $\mathrm{Ni}$ and $\mathrm{Co}$, the PLS obtained after Fe removal was subjected to $\mathrm{AO}$ followed by $\mathrm{AD}$ of the solid residue in two successive steps. The total mass balance of $\mathrm{Ni}, \mathrm{Co}, \mathrm{Mn}, \mathrm{Ca}$, and $\mathrm{Mg}$, during the successive PLS purification steps, is shown in Table 7 and Figure 10. To reduce losses of $\mathrm{Ni}$ and $\mathrm{Co}$ in the $\mathrm{MnO}_{2}$ solids, the acidic dissolution of $\mathrm{AO}$ solids in this series of tests was conducted at $\mathrm{pH}$ equal to 0.8 .

As seen from the results in Table 7 and Figure 10, the recovery of $\mathrm{Ni}$ in the final product was equal to $71.6 \%$ and that of Co to $61.3 \%$. The product stream contained a relatively high amount of $\mathrm{Mg}, \mathrm{Mn}$, and $\mathrm{Ca}$. It was, thus, concluded that the optimization of $\mathrm{Mg}, \mathrm{Mn}$, and Ca separation steps seems to be crucial for the improvement of the quality of the final product.

Table 7. Metal distribution (in $\mathrm{mg}$ ) among streams remaining in the circuit, Fe sludge, $\mathrm{MnO}_{2}$ precipitates, and final $\mathrm{Ni} / \mathrm{Co}$ product stream. $\mathrm{AO}$-alkaline oxidation.

\begin{tabular}{lccccc}
\hline \multicolumn{1}{c}{ Product Stream } & Ni & Co & Mn & Mg & Ca \\
\hline $\begin{array}{l}\text { PLS before Fe removal } \\
\text { Precipitation of trivalent metals at pH 4.0 }\end{array}$ & 1460 & 113.3 & 814 & 15700 & 8340 \\
Mg added for Fe removal & & & & & \\
Removed from the circuit with Fe sludge & 0.0 & 6.71 & 0.0 & 0.0 & 0.0 \\
Aqueous stream from AO steps & 2.04 & 1.01 & 0.55 & 15626 & 8135 \\
Dissolution of AO solids at pH 0.8 & & & & & \\
Removed from the circuit with $\mathrm{MnO}_{2}$ & 412.85 & 36.17 & 517.07 & 91 & 10.45 \\
Ni/Co product stream & 1045.11 & 69.41 & 296.37 & 803 & 195.0 \\
\hline
\end{tabular}




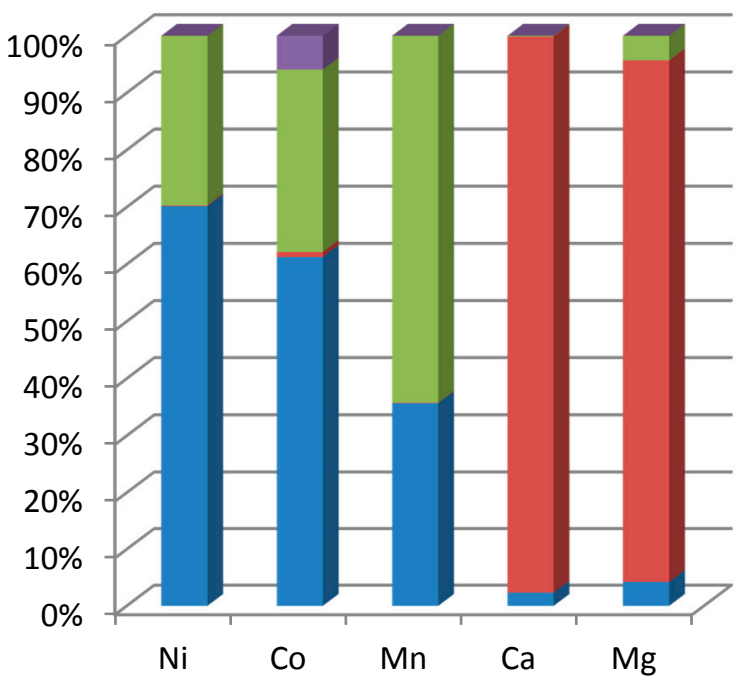

Removed from the circuit with Fe sludge

Removed from the circuit with $\mathrm{MnO} 2$

Remaining in the aqueous phase of AO steps

- Ni-Co product stream

Figure 10. Metal distribution (\%) among the streams remaining in the circuit, Fe sludge, $\mathrm{MnO}_{2}$ precipitates, and final $\mathrm{Ni} / \mathrm{Co}$ product stream.

The $\mathrm{MnO}_{2}$ solid residues produced from the AO/AD process were studied using SEM/EDS analysis and the results are presented in Figure 11. The solids were rich in Mn, but also retained a relatively high content of $\mathrm{Ni}$, close to $2 \%$ in the first and $4 \%$ in the second $\mathrm{AO} / \mathrm{AD}$ stage. They also contained $\mathrm{Mg}$, whose content decreased from $5 \%$ in the first to $2 \%$ in the second $\mathrm{AO} / \mathrm{AD}$ stage.

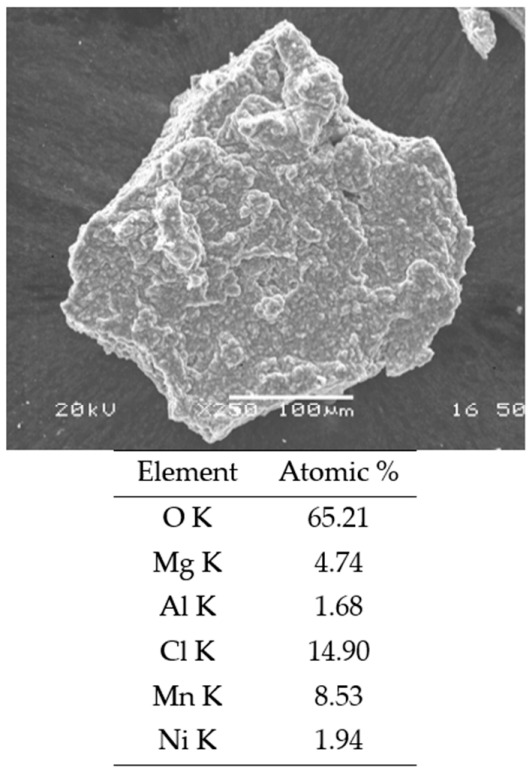

(a) Solid residue of first $\mathrm{AO} / \mathrm{AD}$ stage

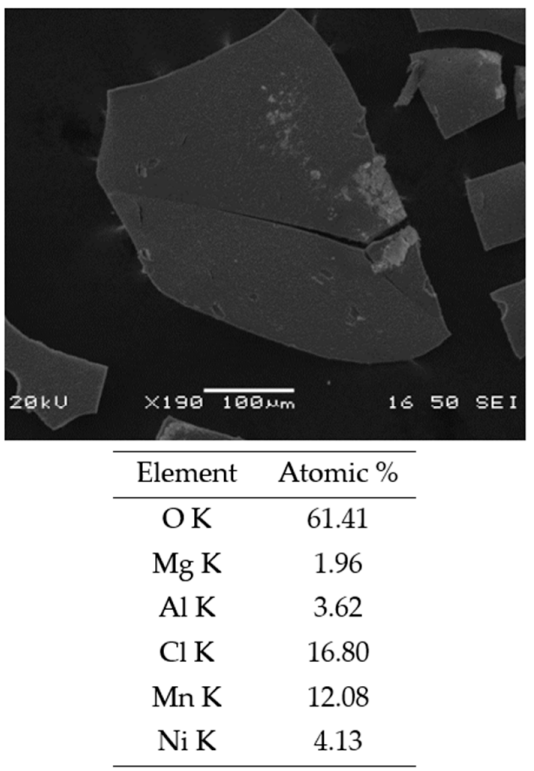

(b) Solid residue of second $\mathrm{AO} / \mathrm{AD}$ stage

Figure 11. SEM and EDS analyses of $\mathrm{MnO}_{2}$ solid residue obtained from the first and second $\mathrm{AO} / \mathrm{AD}$ stages.

\section{Removal of Ca from PLS}

As seen in Table 8, the aqueous stream of the alkaline oxidation steps constituted basically a solution of $\mathrm{MgCl}_{2}$ and $\mathrm{CaCl}_{2}$ with molar concentrations approximately equal to 0.65 and $0.20 \mathrm{M}$. It is known that the presence of $\mathrm{Ca}$ adversely affects the performance of pyrohydrolysis step [32].

For this reason, a step for removing $\mathrm{Ca}$ from the circuit must be included in the flowchart before the pyrohydrolysis treatment, and an option is to precipitate $\mathrm{Ca}$ in the form of gypsum $\mathrm{CaSO}_{4} \cdot \mathrm{xH}_{2} \mathrm{O}$. The residual concentrations of $\mathrm{Ca}$ and $\mathrm{SO}_{4}$ ions in the aqueous solution after calcium sulfate precipitation were estimated using V-Minteq software, assuming that the solution initially contained $0.65 \mathrm{M} \mathrm{MgCl}_{2}$ 
and $0.20 \mathrm{M} \mathrm{CaCl}_{2}$. An amount of $\mathrm{H}_{2} \mathrm{SO}_{4}$ stoichiometrically equivalent to $\mathrm{Ca}(0.20 \mathrm{M})$ was added in this solution, and calculations were carried out assuming precipitation of gypsum $\left(\mathrm{CaSO}_{4} \cdot 2 \mathrm{H}_{2} \mathrm{O}\right)$. Input data and calculated results are presented in Table 8. As seen in the table, the calculated equilibrium concentrations of $\mathrm{Ca}$ and $\mathrm{SO}_{4}$ were equal to $0.08 \mathrm{M}$.

Table 8. Input data and calculated results for gypsum precipitation using V-Minteq software.

\begin{tabular}{ccc}
\hline Component & Initial Composition of Aqueous Phase & Calculated Amount in Equilibrium \\
\hline & Molar Conc. (M) & Molar Conc. (M) \\
$\mathrm{Cg}$ & 0.65 & 0.65 \\
$\mathrm{Cl}$ & 0.20 & 0.08 \\
$\mathrm{H}^{+}$ & 1.70 & 1.70 \\
$\mathrm{SO}_{4}{ }^{-2}$ & 0.40 & 0.40 \\
\hline
\end{tabular}

Pyrohydrolysis of the Aqueous Stream after Calcium Removal

The distribution of species during the thermal process of pyrohydrolysis was estimated based on calculations carried out with the HSC Chemistry software. The composition of the aqueous stream was simulated assuming a mixture containing $0.65 \mathrm{~mol}$ of $\mathrm{MgCl}_{2}, 0.08 \mathrm{~mol}$ of $\mathrm{CaSO}_{4} 2 \mathrm{H}_{2} \mathrm{O}, 0.40 \mathrm{~mol} \mathrm{of} \mathrm{HCl}$, and $55 \mathrm{~mol}$ of $\mathrm{H}_{2} \mathrm{O}$. The release of $\mathrm{HCl}$ and the evolution of $\mathrm{Mg}$ phases as a function of temperature are shown in Figure 12a. The evolution of Ca phases is shown in Figure 12b. Between 200 and 340 ${ }^{\circ} \mathrm{C}$, the release of $\mathrm{HCl}$ was equal to $0.96 \mathrm{~mol}$, and the residual $0.74 \mathrm{~mol}$ of chlorides was bound to the $\mathrm{Mg}(\mathrm{OH}) \mathrm{Cl}$ and $\mathrm{CaCl}_{2}$ compounds. Between 340 and $400^{\circ} \mathrm{C}, \mathrm{Mg}(\mathrm{OH}) \mathrm{Cl}$ decomposed and the released $\mathrm{HCl}$ increased to $1.52 \mathrm{~mol}$. A small amount of $\mathrm{Cl}$, equal $0.18 \mathrm{~mol}$, was retained in the form of $\mathrm{CaCl}_{2}$, until $770{ }^{\circ} \mathrm{C}$. Above this temperature, all the chlorides fed to the pyrohydrolysis step, i.e., $1.70 \mathrm{~mol}$, were released as $\mathrm{HCl}$. At $800^{\circ} \mathrm{C}$, the solid phases of $\mathrm{Mg}$ consisted of oxides $\mathrm{MgO}(0.643 \mathrm{~mol})$ and traces of $\mathrm{MgSO}_{4}(0.007 \mathrm{~mol})$. Calcium was found in the form of $\mathrm{CaSO}_{4}(0.072 \mathrm{~mol})$ with a small amount of $\mathrm{CaO}(0.008 \mathrm{~mol})$.

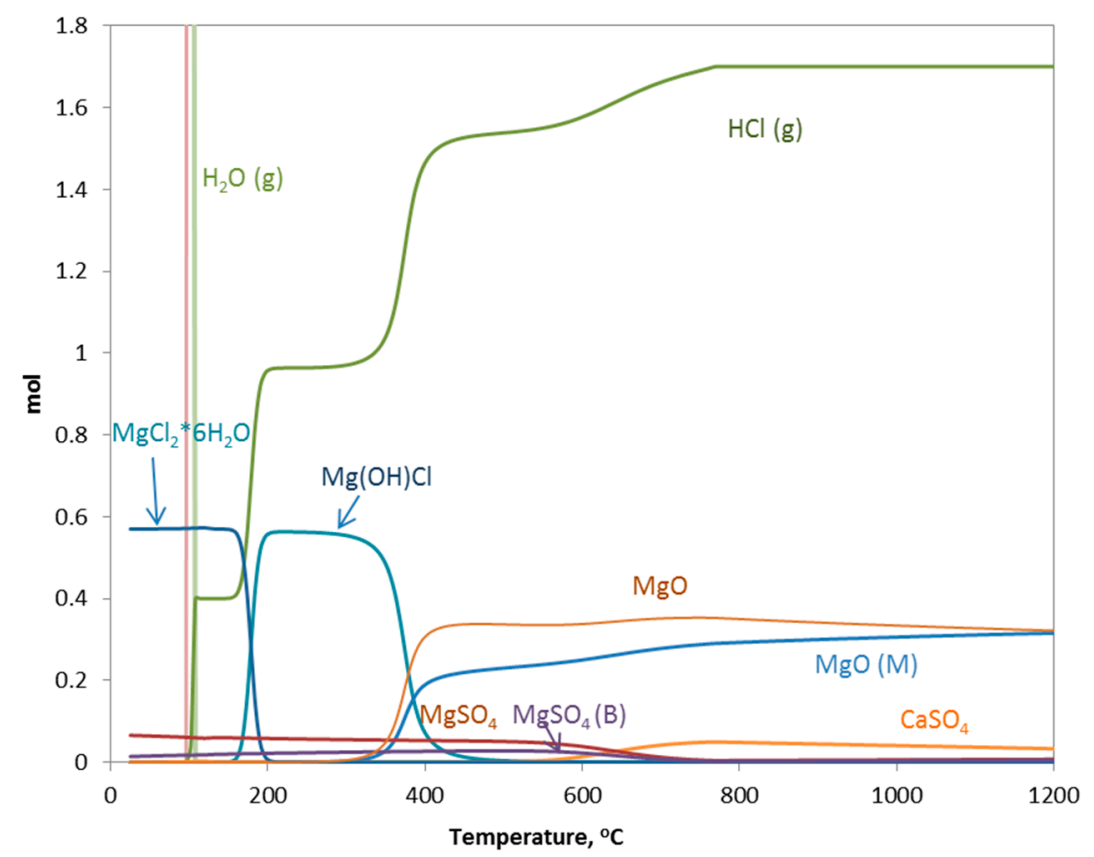

(a)

Figure 12. Cont. 


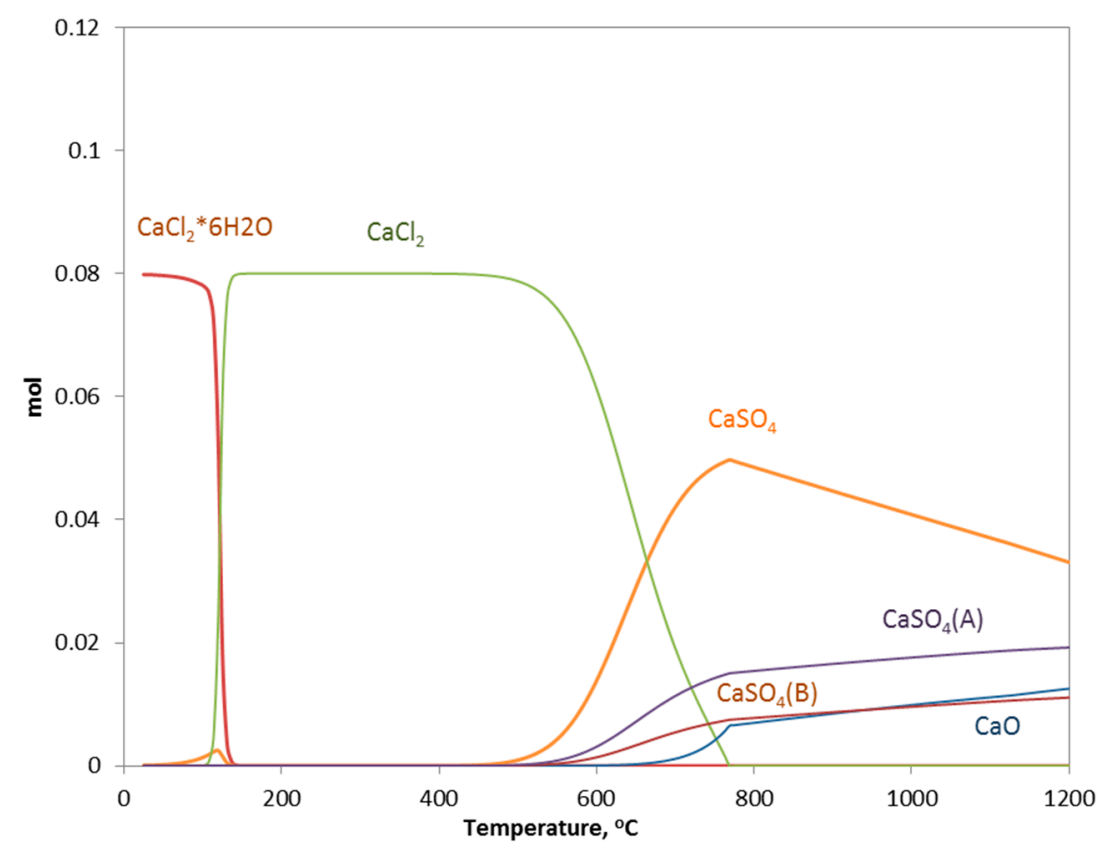

(b)

Figure 12. Produced solid and gas phases from the aqueous stream after calcium sulfate precipitation, increasing the temperature from 25 to $1200{ }^{\circ} \mathrm{C}$, based on HSC equilibrium calculations. (a) Release of $\mathrm{HCl}$ gas and evolution $\mathrm{Mg}$ phases; (b) evolution of Ca phases.

\section{Discussion}

The experimental evaluation of the $\mathrm{HCl}$ process, applying one-step leaching of laterite at $10 \%$ $w / v$ pulp density, indicated that the most important steps determining the final recovery of $\mathrm{Ni}$ and $\mathrm{Co}$ and the purity of $\mathrm{Ni} / \mathrm{Co}$ stream are those involved in the combined $\mathrm{AO} / \mathrm{AD}$ process. Repetitive application of the $\mathrm{AO} / \mathrm{AD}$ treatment steps significantly improved $\mathrm{Mg}$ and $\mathrm{Mn}$ separation from the valuable metals. For instance, the $\mathrm{Mg} / \mathrm{Ni}$ ratio dropped from 6.9 to 0.43 and 0.05 , applying one, two, and three cycles of the combined treatment, respectively.

Operation at $10 \%$ pulp density requires a high excess of water and is unrealistic under industrial conditions. Much closer to the industrial practice is operation at $30 \% \mathrm{~S} / \mathrm{L}$. The initial experimental results (Table 2) indicated that operating at this higher pulp density had the great advantage of suppressing co-dissolution of Fe from $54 \%$ to $1.5 \%$, but the extraction of $\mathrm{Ni}$ dropped from $79 \%$ to $45 \%$ and that of Co from $84 \%$ to $40 \%$.

The CCL mode of operation, at 30\% pulp density, was evaluated experimentally in order to increase the extraction of $\mathrm{Ni}$ and $\mathrm{Co}$ and maintain co-dissolution of $\mathrm{Fe}$ at low levels. Indeed, during $\mathrm{CCL}$, the dissolution of Fe was very low, as expected, on the order of $0.56 \%$, while the extraction of $\mathrm{Ni}$ improved from $45 \%$ to $55 \%$ and that of Co from 40 to $63 \%$. However, the final recoveries of $\mathrm{Ni}$ and Co were low ( $40 \%$ and $38 \%$, respectively) due to additional losses in the subsequent treatment steps. The mass balance of metals, based on the experimental results simulating the CCL operation and the following PLS purification steps, is presented in the flowchart of Figure 13. 


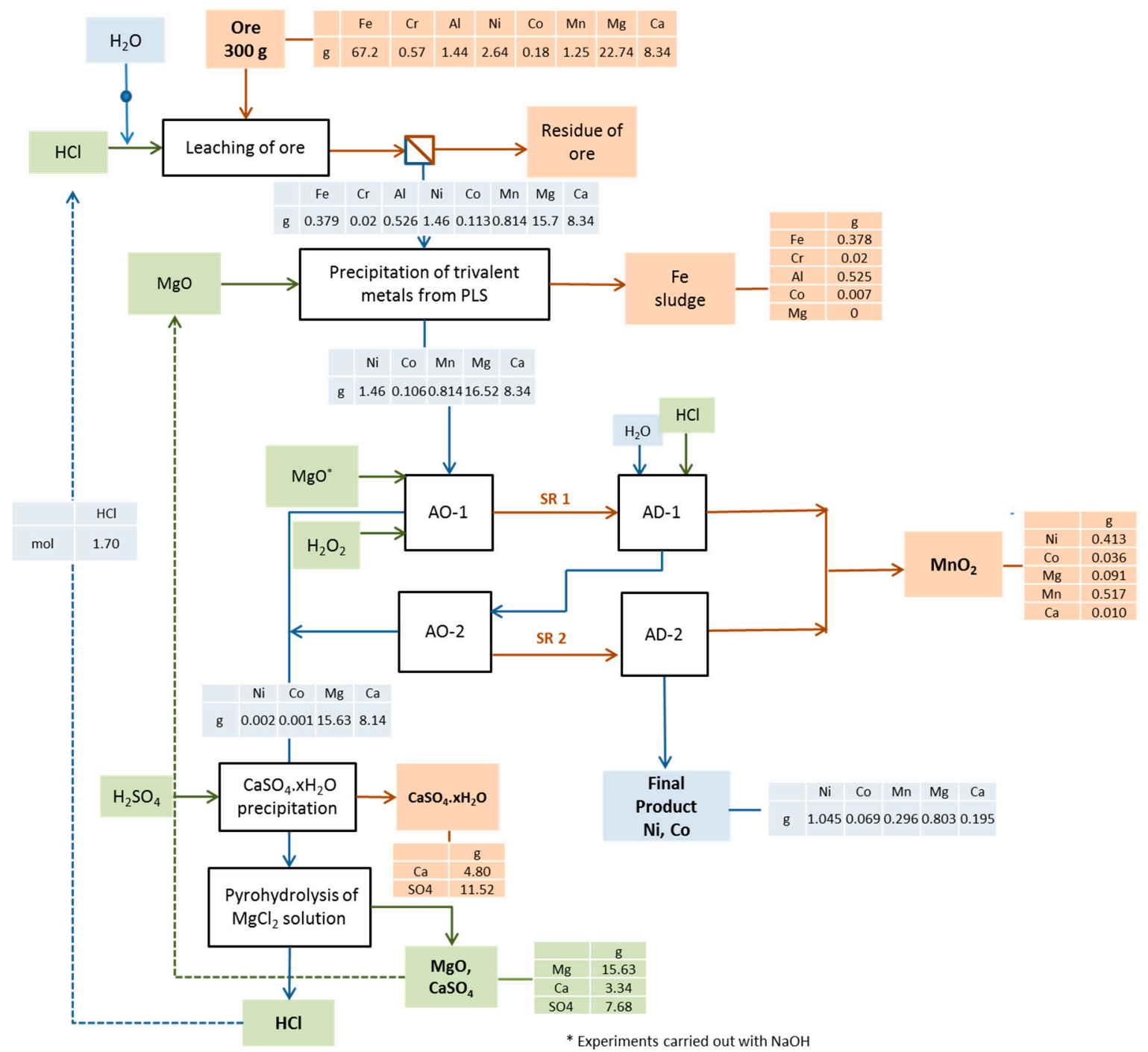

Figure 13. Flowchart simulating CCL operation at 30\% pulp density, including mass balance of metals.

From the mass balance, it was calculated that $45 \%$ of $\mathrm{Ni}$ and $37 \%$ of Co remained in the residue produced after CCL. About $15 \% \mathrm{Ni}$ and $20 \%$ Co were also lost in the $\mathrm{MnO}_{2}$ solids; $64 \%$ of the extracted Mn was removed with the $\mathrm{MnO}_{2}$ solids, while $99 \%$ of the extracted $\mathrm{Mg}$ was fed in the pyrohydrolysis step for $\mathrm{MgO}$ recovery and $\mathrm{HCl}$ regeneration. Co-extraction of $\mathrm{Ca}$ had a negative effect on $\mathrm{MgO}$ recovery and $\mathrm{HCl}$ regeneration; thus, $\mathrm{Ca}$ had to be removed from the circuit in the form of gypsum before the pyrohydrolysis step. It was estimated that, in this case, $60 \%$ of the extracted Ca would be removed as gypsum and $40 \%$ would be recovered as $\mathrm{CaSO}_{4}$, together with the $\mathrm{MgO}$ solids during the pyrohydrolysis step.

It is evident that the two crucial processes of the flowchart in order to maximize $\mathrm{Ni}$ and $\mathrm{Co}$ extraction and reduce their losses in the solid residues were the $\mathrm{CCL}$ and $\mathrm{AO} / \mathrm{AD}$ operations.

According to Rice [11], it is not possible to increase Ni concentration in the leach liquor by applying a CCL type of operation due to the passivation caused as a result of the formation of a product layer around the ore particles. Most probably, this is the mechanism explaining the high $\mathrm{Ni}$ and Co losses in the residue of CCL. As seen in Table 4, approximately $20 \mathrm{~g} / \mathrm{L}$ iron precipitated during the leaching of $300 \mathrm{~g}$ of fresh ore at step $1 \mathrm{a}^{\prime}$. It is possible that the iron oxide precipitates were attached on the surface of the ore particles, inhibiting further extraction of $\mathrm{Ni}$ and $\mathrm{Co}$. A possible way of overcoming this problem could be to carry out leaching in the presence of an inert abrasive medium, e.g., quartz particles of gravel size, in order to avoid the formation of this passivation layer. 
Regarding Ni and Co losses in the Mn solids, they were primarily due to the fact that the oxidation of $\mathrm{Mn}(\mathrm{II})$ to the tetravalent state, $\mathrm{Mn}(\mathrm{IV})$, was incomplete. For the optimization of this step, it is, thus, necessary to increase the efficiency of $\mathrm{Mn}$ (II) oxidation. In addition to $\mathrm{H}_{2} \mathrm{O}_{2}$, several other oxidants were tested for this purpose, including $\mathrm{O}_{3}$, an $\mathrm{SO}_{2} / \mathrm{O}_{2}$ mixture, peroxy-sulfuric acids, hypochlorite, and chlorate $[15,33]$. The investigated flowchart was based on the use of $\mathrm{HCl}$; it is, thus, better to avoid the use of sulfur-based oxidants. The use of $\mathrm{ClO}_{2}$ as tested by Park et al. [33] would not alter the composition of aqueous streams and could be an interesting alternative.

Another option for the efficient separation of $\mathrm{Mn}$ from $\mathrm{Ni}$ and Co comprises the following steps: (i) precipitation of $\mathrm{Ni}, \mathrm{Co}$, and $\mathrm{Mn}$ as hydroxides, and (ii) leaching of the precipitates with ammonia in the presence of air and $\mathrm{CO}_{2}$ to selectively dissolve $\mathrm{Ni}$ and $\mathrm{Co}$ as ammine complexes, while $\mathrm{Mn}$ is left in the solid residue as manganese carbonate [34].

\section{Conclusions}

An atmospheric leaching process based on the use of hydrochloric acid was evaluated for $\mathrm{Ni}$ and Co extraction from a low-grade saprolitic laterite. The main advantage of using $\mathrm{HCl}$, instead of other acids like $\mathrm{H}_{2} \mathrm{SO}_{4}$, is the fact that $\mathrm{HCl}$ can effectively extract both $\mathrm{Ni}$ and $\mathrm{Co}$ from the laterite ore, while $\mathrm{H}_{2} \mathrm{SO}_{4}$ is primarily efficient for $\mathrm{Ni}$ extraction. On the other hand, $\mathrm{HCl}$ can be regenerated and recycled in the leaching stage.

The leaching was carried out at 30\% pulp density, applying a counter-current mode of operation, in order to better simulate industrial-scale operations and maintain Fe dissolution at low levels. This mode of operation was indeed very efficient regarding Fe dissolution, which was maintained at $0.6 \%$, but proved to have a negative effect on $\mathrm{Ni}$ and Co extraction, which was limited to $55 \%$ and $63 \%$, respectively, probably due to the passivation of ore minerals by secondary Fe-oxide precipitation products.

The treatment of PLS involved a series of simple precipitation steps. In this series of operations, the most crucial step was found to be the separation of $\mathrm{Mn}$ from the valuable $\mathrm{Ni}$ and Co metals. The adopted process was based on the oxidation of $\mathrm{Mn}(\mathrm{II})$ to $\mathrm{Mn}(\mathrm{IV})$ in order to form a stable $\mathrm{MnO}_{2}$ oxide, which would remain in the solid phase under acidic conditions, while Ni and Co could be selectively recovered in the aqueous phase. However, the oxidation of $\mathrm{Mn}$ was not complete, and a relatively high amount of $\mathrm{Ni}$ and $\mathrm{Co}$ was retained in the solids, reducing the final recovery of the two elements to the levels of $40 \%$ for $\mathrm{Ni}$ and $38 \%$ for $\mathrm{Co}$. At this stage, additional tests were carried out to overcome some of these drawbacks and improve the overall efficiency of the process.

Author Contributions: C.M. performed the literature search, carried out experiments and analytical techniques, analyzed data, and wrote a first draft of the paper. N.P. designed the experiments, critically analyzed results, and wrote the paper. A.X. designed the experiments and reviewed the paper. K.K. designed the experiments, contributed in the analysis of the results, and reviewed the paper.

Acknowledgments: The authors would like to acknowledge the financial support of the European Commission in the frame of Horizon 2020 project "Metal recovery from low-grade ores and wastes", www.metgrowplus.eu, Grant Agreement n. 690088.

Conflicts of Interest: The authors declare no conflicts of interest.

\section{References}

1. McDonald, R.G.; Whittington, B.I. Atmospheric acid leaching of nickel laterites review. Part I. Sulphuric acid technologies. Hydrometallurgy 2008, 91, 35-55. [CrossRef]

2. Zhang, P.; Guo, Q.; Wei, G.; Qu, J.; Qi, T. Precipitation of $\alpha-\mathrm{Fe}_{2} \mathrm{O}_{3}$ and recovery of Ni and Co from synthetic laterite leaching solutions. Hydrometallurgy 2015, 153, 21-29. [CrossRef]

3. Feng, Q.; Zhao, W.; Wen, S. Surface modification of malachite with ethanediamine and its effect on sulfidization flotation. Appl. Surf. Sci. 2018, 436, 823-831. [CrossRef]

4. Whittington, B.I.; Muir, D. Pressure acid leaching of nickel laterites: A review. Miner. Process. Extr. Metall. Rev. 2000, 21, 527-599. [CrossRef] 
5. McDonald, R.G.; Whittington, B.I. Atmospheric acid leaching of nickel laterites review. Part II. Chloride and bio-technologies. Hydrometallurgy 2008, 91, 56-69. [CrossRef]

6. Komnitsas, K. Kinetic Study of Laterite Atmospheric Leaching with Sulfuric Acid. Master's Thesis, National Technical University of Athens, Athens, Greece, 1983. (In Greek)

7. Kontopoulos, A. Sulphuric acid leaching of laterites. In Extraction and Processing Division Congress; Gaskell, D.R., Ed.; The Minerals, Metals and Materials Society: Warrendale, PA, USA, 2001; pp. 147-163.

8. Halikia, I. Parameters influencing kinetics of nickel extraction from a Greek laterite during leaching with sulphuric acid at atmospheric pressure. Trans. Inst. Min. Metall. Sect. C 1991, 100, C154-C164.

9. Agatzini-Leonardou, S.; Dimaki, D. Heap leaching of poor nickel laterites by sulphuric acid at ambient temperatures. In Hydrometallurgy '94; Chapman and Hall: London, UK, 1994; pp. 193-208.

10. Komnitsas, K.; Petrakis, E.; Pantelaki, O.; Kritikaki, A. Column leaching of Greek low grade limonitic laterites. Minerals 2018, 8, 377. [CrossRef]

11. Tzeferis, P.G.; Agatzini-Leonardou, S. Leaching of nickel and iron from Greek non-sulphide nickeliferous ores by organic acids. Hydrometallurgy 1994, 36, 345-360. [CrossRef]

12. Tzeferis, P.G. Leaching of a low grade hematitic laterite ore using fungi and biologically produced acid metabolites. Int. J. Miner. Process. 1994, 42, 267-283. [CrossRef]

13. Mystrioti, C.; Papassiopi, N.; Xenidis, A.; Komnitsas, K. Comparative Evaluation of Sulfuric and Hydrochloric Acid Atmospheric Leaching for the Treatment of Greek Low Grade Nickel Laterites. In Extraction 2018, Proceedings of the First Global Conference on Extractive Metallurgy, The Minerals, Metals $\mathcal{E}$ Materials Series, Ottawa, QC, Canada, 26-29 August 2018; Davis, B.R., Moats, M.S., Wang, S., Gregurek, D., Kapusta, J., Battle, T.P., Schlesinger, M.E., Flores, G.R.A., Jak, E., Goodall, G., et al., Eds.; Springer: Cham, Switzerland, 2018; pp. 1753-1764.

14. Rice, N.M. A hydrochloric acid process for nickeliferous laterites. Miner. Eng. 2016, 88, 28-52. [CrossRef]

15. Baba, A.A.; Ibrahim, L.; Adekola, F.A.; Bale, R.B.; Ghosh, M.K.; Sheik, A.R.; Pradhan, S.R.; Ayanda, O.S.; Folorunsho, I.F. Hydrometallurgical Processing of Manganese Ores: A Review. J. Miner. Mater. Charact. Eng. 2014, 2, 230-247. [CrossRef]

16. Agatzini-Leonardou, S.; Tsakiridis, P.E.; Oustadakis, P.; Karidakis, T.; Katsiapi, A. Hydrometallurgical process for the separation and recovery of nickel from sulphate heap leach liquor of nickeliferous laterite ores. Miner. Eng. 2009, 22, 1181-1192. [CrossRef]

17. Meng, L.; Qua, J.; Guo, Q.; Xie, K.; Zhang, P.; Han, L.; Zhang, G.; Qi, T. Recovery of Ni, Co, Mn, and Mg from nickel laterite ores using alkaline oxidation and hydrochloric acid leaching. Sep. Purif. Technol. 2015, 143, 80-87. [CrossRef]

18. Wang, K.; Li, J.; McDonald, R.G.; Browner, R.E. Iron, aluminium and chromium co-removal from atmospheric nickel laterite leach solutions. Miner. Eng. 2018, 116, 35-45. [CrossRef]

19. White, D.T.; Gillaspie, J.D. Atmospheric leaching of nickel laterites with iron precipitation. In Proceedings of the Alta Conference Proceedings, Perth, Australia, 23-30 May 2015.

20. Willis, B. Downstream processing options for nickel laterite heap leach liquors. In ALTA 2007 Nickel/Cobalt 12; ALTA Metallurgical Services: Melbourne, Australia, 2007; 25p.

21. Readett, D.; Sullivan, J. GME's NiWest Nickel Project-ongoing development of Ni laterite heap leach, sx-ew process. In Proceedings of the ALTA 2015 Conference, Perth, Australia, 23-30 May 2015.

22. Demopoulos, G.P. Aqueous precipitation and crystallization for the production of particulate solids with desired properties. Hydrometallurgy 2009, 96, 199-214. [CrossRef]

23. Filippou, D.; Choi, Y. A contribution to the study of iron removal from chloride leach solutions. In Chloride Metallurgy, Proc. 32nd Annual CIM Hydrometallurgical Conference; Peek, E., van Weert, G., Eds.; CIM: Montreal, QC, USA, 2002; Volume 2, p. 729.

24. Beukes, J.P.; Giesekke, E.W.; Elliott, W. Nickel retention by goethite and hematite. Miner. Eng. 2000, 13, 1573-1579. [CrossRef]

25. Demopoulos, G.P.; Li, Z.; Becze, L.; Moldoveanu, G.; Cheng, T.; Harris, G.B. New technologies for $\mathrm{HCl}$ regeneration in chloride hydrometallurgy. World Metall. ERZMETALL 2008, 61, 84-93.

26. Feldmann, T.; Demopoulos, G.P. Influence of impurities on crystallization kinetics of calcium sulfate dihydrate and hemihydrate in strong $\mathrm{HCl}-\mathrm{CaCl}_{2}$ solutions. Ind. Eng. Chem. Res. 2013, 52, 6540-6549. [CrossRef] 
27. Feldmann, T.; Demopoulos, G.P. Effects of crystal habit modifiers on the morphology of calcium sulfate dihydrate grown in strong $\mathrm{CaCl} 2-\mathrm{HCl}$ solutions. J. Chem. Technol. Biotechnol. 2014, 89, 1523-1533. [CrossRef]

28. Gustafsson, J.P. Visual MINTEQ, Version 3.0: A Window Version of MINTEQA2, Version 4.0. 2010. Available online: http:/ / www.lwr.kth.se/english/OurSoftware/Vminteq (accessed on 10 April 2018).

29. BSI. EN 12457.02: Characterization of Waste_Leaching-Compliance Test for Leaching of Granular Waste Materials and Sludges-Part 2: One Stage Batch Test at a Liquid to Solid Ratio of $10 \mathrm{l} / \mathrm{kg}$ for Materials with Particle Size below $4 \mathrm{~mm}$ (without or with Size Reduction); BSI: London, UK, 2002.

30. Kosova, N.; Devyatkina, E.; Kaichev, V. Mixed layered Ni-Mn-Co hydroxides: Crystal structure, electronic state of ions, and thermal decomposition. J. Power Sources 2007, 174, 735-740. [CrossRef]

31. Zhou, F.; Zhao, X.; van Bommel, A.; Rowe, A.; Dahn, J. Coprecipitation synthesis of $\mathrm{Ni}_{x} \mathrm{Mn}_{1-\mathrm{x}}(\mathrm{OH})_{2}$ mixed hydroxides. Chem. Mater. 2010, 22, 1015-1021. [CrossRef]

32. Yildirim, M.; Akarsu, H. Preparation of magnesium oxide (MgO) from dolomite by leach precipitation pyrohydrolysis process. Physicochem. Probl. Miner. Process. 2010, 44, 257-272.

33. Park, K.H.; Kim, H.I.; Das, R.P. Selective Acid Leaching of Nickel and Cobalt from Precipitated Manganese Hydroxide in the Presence of Chlorine Dioxide. Hydrometallurgy 2005, 78, 271-277. [CrossRef]

34. Manson, P.G.; Groutsch, J.V.; Mayze, R.S.; White, D.R.S. Process Development and Plant Design for the Cawse Nickel Project; ALTA Metallurgy Service: Perth, Australia, 1997.

(C) 2018 by the authors. Licensee MDPI, Basel, Switzerland. This article is an open access article distributed under the terms and conditions of the Creative Commons Attribution (CC BY) license (http://creativecommons.org/licenses/by/4.0/). 